\title{
Ten-eleven translocation protein 1 modulates medulloblastoma progression
}

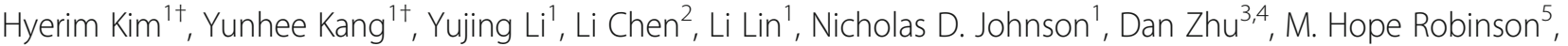 \\ Leon McSwain ${ }^{5}$, Benjamin G. Barwick ${ }^{4,6}$, Xianrui Yuan ${ }^{7}$ Xinbin Liao ${ }^{7,8}$, Jie Zhao ${ }^{7,8}$, Zhiping Zhang ${ }^{7,8}$, Qiang Shu', \\ Jianjun Chen ${ }^{10}$, Emily G. Allen ${ }^{1}$, Anna M. Kenney ${ }^{5,6}$, Robert C. Castellino ${ }^{5,11}$, Erwin G. Van Meir ${ }^{3,4,6}$, \\ Karen N. Conneely ${ }^{1}$, Paula M. Vertino ${ }^{4,6}$, Peng Jin ${ }^{1 *}$ (D) and Jian Li ${ }^{1,7,8^{*}}$
}

\footnotetext{
* Correspondence: peng.jin@emory. edu; lj.nrsg@csu.edu.cn ${ }^{\dagger}$ Hyerim Kim and Yunhee Kang contributed equally to this work. 'Department of Human Genetics, Emory University School of Medicine, Atlanta, GA 30322, USA Full list of author information is available at the end of the article
}

\begin{abstract}
Background: Medulloblastoma (MB) is the most common malignant pediatric brain tumor that originates in the cerebellum and brainstem. Frequent somatic mutations and deregulated expression of epigenetic regulators in MB highlight the substantial role of epigenetic alterations. 5-hydroxymethylcytosine $(5 \mathrm{hmC})$ is a highly abundant cytosine modification in the developing cerebellum and is regulated by ten-eleven translocation (TET) enzymes.

Results: We investigate the alterations of $5 \mathrm{hmC}$ and TET enzymes in $\mathrm{MB}$ and their significance to cerebellar cancer formation. We show total abundance of $5 \mathrm{hmC}$ is reduced in MB, but identify significant enrichment of MB-specific $5 \mathrm{hmC}$ marks at regulatory regions of genes implicated in stem-like properties and Nanog-binding motifs. While TET1 and TET2 levels are high in MBs, only knockout of Tet1 in the smoothened (SmoA1) mouse model attenuates uncontrolled proliferation, leading to a favorable prognosis. The pharmacological Tet1 inhibition reduces cell viability and platelet-derived growth factor signaling pathway-associated genes.
\end{abstract}

Conclusions: These results together suggest a potential key role of $5 \mathrm{hmC}$ and indicate an oncogenic nature for TET1 in MB tumorigenesis, suggesting it as a potential therapeutic target for MBs.

Keywords: Medulloblastoma, 5-hydroxymethylcytosine, TET1, Stem-like property, NANOG, PDGF signaling pathway

\section{Background}

Medulloblastoma $(\mathrm{MB})$ is the most common malignant pediatric brain tumor that originates in the cerebellum and brainstem. While this embryonal tumor has a lower mutation rate than adult solid tumors, frequent somatic mutations and deregulated expression of epigenetic regulators, including chromatin remodeling genes and histone modifiers, highlight the substantial role of epigenetic alterations in its formation/development/genesis [1, 2]. Indeed, DNA methylation signature is a key factor for MB molecular stratification, together with transcriptional signature, into four groups:

(c) The Author(s). 2021 Open Access This article is licensed under a Creative Commons Attribution 4.0 International License, which permits use, sharing, adaptation, distribution and reproduction in any medium or format, as long as you give appropriate credit to the original author(s) and the source, provide a link to the Creative Commons licence, and indicate if changes were made. The images or other third party material in this article are included in the article's Creative Commons licence, unless indicated otherwise in a credit line to the material. If material is not included in the article's Creative Commons licence and your intended use is not permitted by statutory regulation or exceeds the permitted use, you will need to obtain permission directly from the copyright

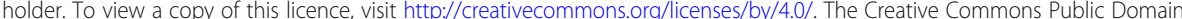
Dedication waiver (http://creativecommons.org/publicdomain/zero/1.0/) applies to the data made available in this article, unless otherwise stated in a credit line to the data. 
Wingless (WNT), Sonic Hedgehog (SHH), Group 3, and Group 4 [2-5]. Studies in mice also support the importance of epigenome regulation in MB: targeting chromatin remodeling with a combination of DNA methyltransferases (DNMT) inhibitor 5-aza-2' deoxycytidine (5-aza-dC) and histone deacetylases (HDAC) inhibitor valproic acid (VPA) effectively inhibits tumor formation in the patched homolog (Ptch) heterozygous mice, a model of SHH-MB [6], and antagonizing methyl-CpG binding protein methylCpG binding domain protein 2 (MBD2) inhibits MB xenografts [7]. Despite the significance of the epigenome in $\mathrm{MB}$, there have been limited studies investigating the dynamic nature of cytosine modifications and enzymes involved in the process.

In humans, cerebellar development involves active neuronal maturation and circuit formation from the third trimester up to 2 years after birth [8,9]; thus, precise and timely gene regulation during this period is critical for neurogenesis from neural progenitors. In mice, this process is similar, but is easier to study as it occurs within the first 3 weeks postnatally. During murine cerebellar maturation, while a small increase in global levels of 5-methylcytosine $(5 \mathrm{mC})$ is detected, a much more dramatic change in the abundance of its oxidative derivative, 5 -hydroxymethylcytosine $(5 \mathrm{hmC})$, occurs, reaching approximately 0.4 to $0.9 \%$ of total cytosines $[10,11]$. In addition, $5 \mathrm{hmC}$ is enriched at cerebellar-specific enhancers and the exon start site of highly expressed genes involved in axon guidance and ion channels [11, 12]. This evidence suggests $5 \mathrm{hmC}$ plays a role in establishing and maintaining cell identity during the period of circuit formation. Interestingly, the abundance of $5 \mathrm{hmC}$ is significantly reduced in many solid tumors, such as melanoma [13], prostate, breast, liver, colon cancers [14, 15], and brain tumors [15-17], which is associated with shorter postoperative survival [18]. Moreover, enzymatic impairment caused by somatic mutations and copy number alterations or the deregulated expression of TET enzymes is frequently identified in many cancers and is often associated with unfavorable prognosis [19-22].

To investigate the alterations of $5 \mathrm{hmC}$ and TET enzymes in $\mathrm{MB}$ and their significance to cerebellar cancer formation, we employed genome-wide $5 \mathrm{hmC}$ profiling and the SmoA1 mouse MB model. Consistent with previous findings in different tumors, we show that $5 \mathrm{hmC}$ is depleted in $\mathrm{MB}$, but identify significant enrichment of MB-specific $5 \mathrm{hmC}$ marks at regulatory regions of genes implicated in stem-like properties and Nanog-binding motifs. Moreover, the abolishment of Tet1 yielded a more favorable prognosis in the SmoA1 mouse MB model, and pharmacological inhibition of Tet1 expression reduced cell viability and suppressed platelet-derived growth factor (PDGF) signaling pathway. Collectively, these data suggest that upregulated Tet1 may contribute to maintaining stem-like properties in $\mathrm{MB}$, validating it as a potential therapeutic target for MBs.

\section{Results}

\section{Decreased $5 \mathrm{hmC}$ level is associated with MB prognosis}

Previous studies have found significant depletion of $5 \mathrm{hmC}$ across many human cancer genomes compared to those of corresponding normal tissues [13, 23-26]. To further explore this epigenetic characteristic in $\mathrm{MB}$, we first examined $5 \mathrm{hmC}$ levels using ultrahigh-performance liquid chromatography-tandem mass-spectrometry (UHPLC-MS/ MS) analysis in normal cerebellar tissues without neurological disorders $(n=5)$ and in 
primary MB tissues $(n=24)$. In normal tissues from children between 3 and 18 years of age, $5 \mathrm{hmC}$ levels were confined to a narrow range (0.80- to 1.15 -fold compared to the mean value (Fig. 1a, b) [12]. In contrast, we identified substantially lower levels in $\mathrm{MB}$ tissues with an average of 0.44 -fold global $5 \mathrm{hmC}$ levels relative to normal of comparable age $(p<0.001$; Fig. 1a, b). In an independent cohort, we consistently observed a significant reduction of $5 \mathrm{hmC}$ levels in $\mathrm{MB}(n=5)$ compared to age-matched normal without marked neurological disorders $(n=6)$ using both dot blot assay and UHPLCMS/MS analysis (Additional file 1: Fig. S1a, b), suggesting that the reduction of $5 \mathrm{hmC}$ is a characteristic for MB. Although there was little variation in $5 \mathrm{hmC}$ levels between normal cerebellar tissues, $\mathrm{MB}$ exhibited significant intertumoral variation in $5 \mathrm{hmC}$ levels with 0.06 to 0.84 -fold differences (Fig. 1a, b). In some cases, $5 \mathrm{hmC}$ levels were almost undetected whereas for other levels were similar to those seen in normal tissues (Fig. 1b). A notable linear correlation between $5 \mathrm{hmC}$ levels and prognosis $\left(n=24, R^{2}=\right.$ 0.3886, $p<0.001$; Fig. 1c) was also observed and was a better indicator of prognosis than age at diagnosis (Additional file 1: Fig. S1c).

\section{Dysregulation of TET expression in MBs}

We next investigated the cause of $5 \mathrm{hmC}$ depletion in MB. DNA methylation is a prerequisite for $5 \mathrm{hmC}$ generation in vivo; therefore, genomic hypomethylation can lead to loss of $5 \mathrm{hmC}$ in tumors. In addition, $5 \mathrm{hmC}$ loss results from hyperproliferation, as there is no mechanism of maintaining $5 \mathrm{hmC}$ levels [27]. Other plausible mechanisms are inactivating mutations of TET enzymes (TET1, TET2, TET3) which are responsible
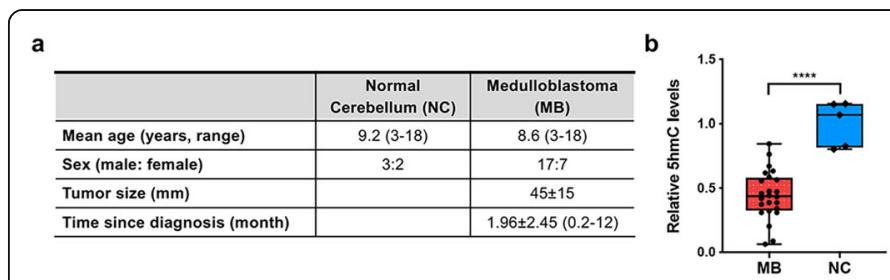

d

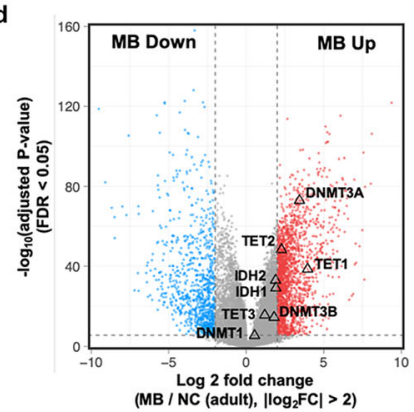

e

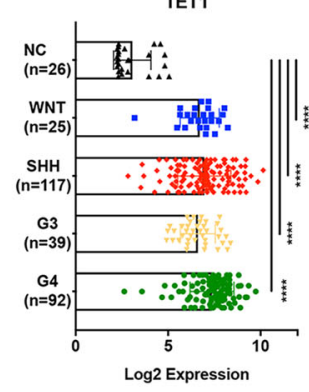

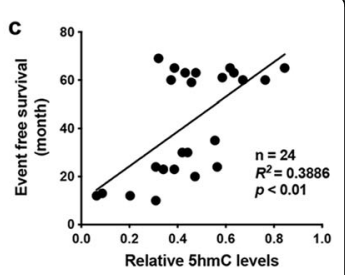

TET2

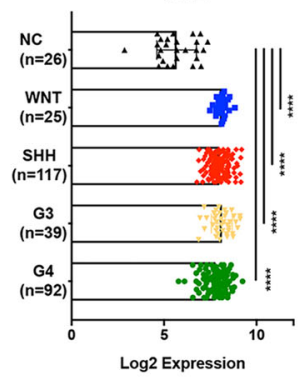

Fig. 1 Loss of 5-hydroxymethylation is a hallmark of MBs. a Table illustrates sample information (age, sex, tumor size, and time since diagnosis) of MBs and normal cerebella (NC). $\mathbf{b}$ UHPLC-MS/MS analysis shows a significant decrease of total $5 \mathrm{hmC}$ levels in MBs $(n=24)$ compared with age-matched normal cerebella (NC) $(n=5)\left({ }^{* * * *} p<0.001\right)$. c Linear correlation between $5 \mathrm{hmC}$ abundance in MBs and prognosis. Lower $5 \mathrm{hmC}$ level is associated with worse prognosis $\left(R^{2}=0.3866, p<0.01\right)$. $\mathbf{d}$ Volcano plot showing distribution of differentially expressed genes in MBs, with log2 fold change of MB/NC on $x$-axis and $P$ values on $y$-axis. Genes with log2 fold change $>2$ are indicated in red, and genes with log 2 fold change $<-2$ are indicated in blue (FDR < 0.05). e Expression level of TET1 and TET2 in each molecular subgroup of MB $(n=273)$ and NC $(n=26)(p<0.001)$. G3: group3, G4: group 4 
for converting $5 \mathrm{mC}$ to $5 \mathrm{hmC}$ or indirect inhibition of TET enzymatic activity caused by the oncometabolite 2-hydroxyglutarate that accumulates in tumors with isocitrate dehydrogenase 1/2 (IDH1/2) mutations and interferes with $\alpha$-ketoglutarate-dependent oxygenases, including the TET enzymes [28, 29]. Querying four publicly available datasets (from Broad, the International Cancer Genome Consortium (ICGC), the Pediatric Cancer Genome Project (PCGP) and SickKids using cBioPortal [30, 31]) showed only three out of 300 patients had putative driving mutations in any of the TET enzymes (truncating mutations of TET1 or TET2) or missense mutation of IDH1 genes, indicating that genetic alterations are not the cause of loss of $5 \mathrm{hmC}$ in most cases (Additional file 1: Fig. S1d). In addition, no focal amplification/deletion of enzymes involved in cytosine dynamics has been observed in previous studies [32]. To explore deregulated expression patterns of enzymes involved in $5 \mathrm{hmC}$ generation, we performed a meta-analysis of 8 different publicly available gene expression datasets containing 273 human MB samples and 31 fetal and adult human cerebellar tissue controls (Additional file 2: Table S1). This analysis revealed significant upregulation of DNMT3A, TET1, and TET2 genes in MB compared to adult normal controls (FDR < 0.05 and $\log 2$ fold changes $>2$, Fig. 1d), at expression levels comparable to those observed in fetal cerebellar tissues (Additional file 1: Fig. S1). Since TET enzymes are more directly involved in $5 \mathrm{hmC}$ formation, we further investigated whether TET1 and TET2 expression is regulated by particular pathways within the different MB groups. While we observed intertumoral variation, there is no significant difference in TET1/2 mRNA levels across MB molecular groups (Fig. 1e), suggesting that their regulation may be independent of the distinct signaling pathways found in each subgroup. Given that high levels of TET1 and TET2 mediate epigenetic reprogramming by passive and active DNA demethylation processes in primordial germ cells (PGCs) [33-35], high levels of TET1/2 in MB could underlie global hypomethylation in PGC [36].

\section{Distinct $5 \mathrm{hmC}$ signature in MBs}

Global $5 \mathrm{hmC}$ levels are highly variable depending on tissue of origin and developmental stage. The regional distribution of $5 \mathrm{hmC}$ is highly tissue-specific, and $5 \mathrm{hmC}$ is enriched at regulatory regions of highly transcribed genes in glioblastoma [37-39]. Thus, we explored differentially hydroxymethylated genomic regions (DhMRs) using $16 \mathrm{MB}$ primary tissues and 6 age-matched normal cerebella (Additional file 3: Table S2) by employing a previously established chemical labeling and affinity purification method coupled with high-throughput sequencing [10]. Principal component analysis showed substantial similarity of $5 \mathrm{hmC}$ patterns in normal cerebella $(n=6)$ regardless of age (mean age $=11.5$ years old, range $=5$ to 19 years old $)$, but tumors $(n=16$, mean age $=$ 9.4 years old, range $=1.5$ to 34 years old) showed divergent $5 \mathrm{hmC}$ patterns (Additional file 1: Fig. S2). We identified 24,006 DhMRs that show increased hydroxymethylation in MBs (gain-of-5hmC) and 85,738 DhMRs that show decreased hydroxymethylation in MBs (loss-of-5hmC) using DESeq2 [40] (Fig. 2a and Additional file 4: Table S3). Gain-of-5hmC showed significant enrichment at chromosome 2, 15, and 20, whereas loss-of-5hmC was mainly enriched at chromosome 1 and 19 (Additional file 1: Fig. S2). Given the significant association between elevated $\mathrm{C}$ to $\mathrm{G}$ transversions with asymmetrically hydroxymethylated sites in cancer genomes [41], further investigation is 


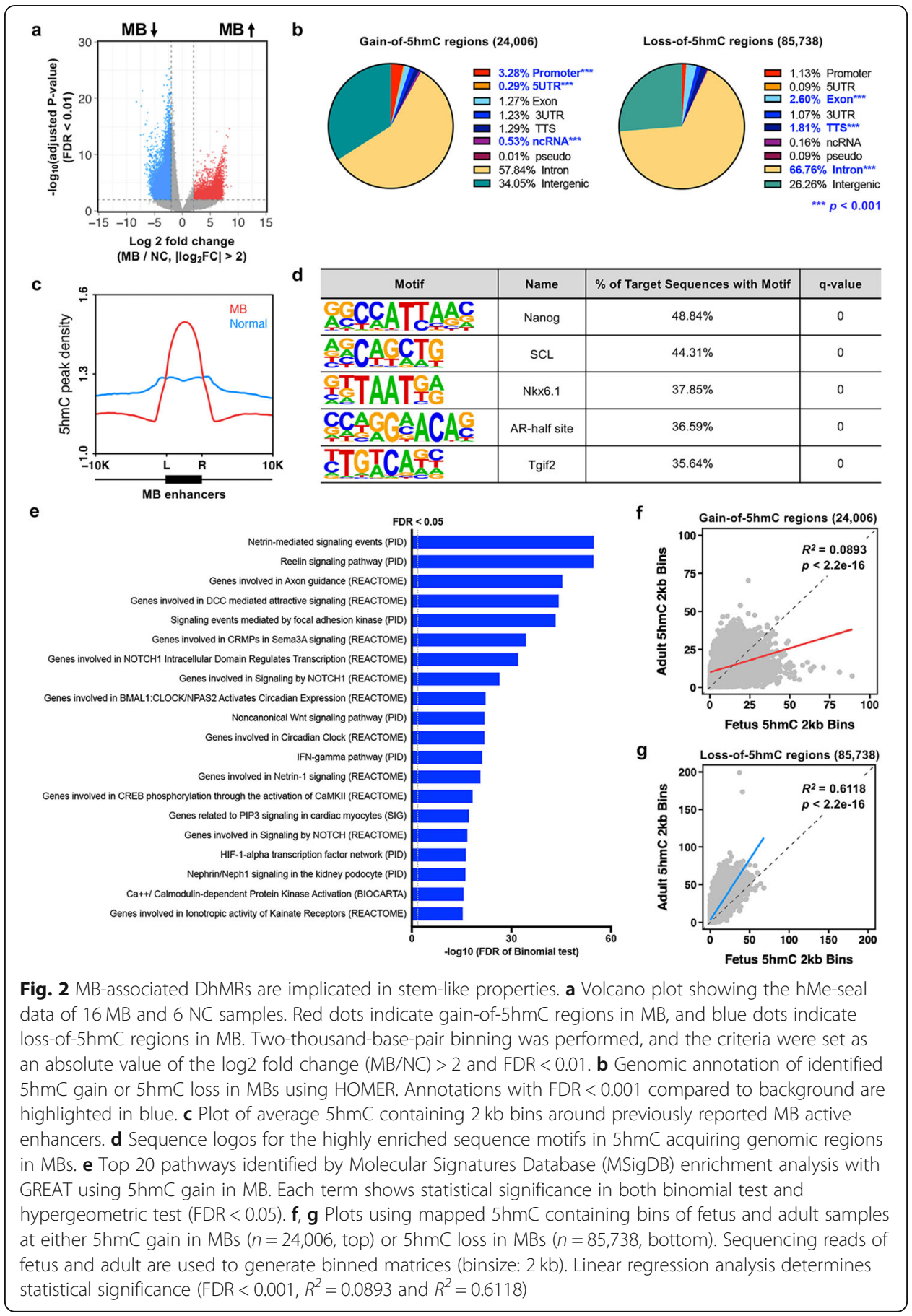

needed to determine the direct correlation between $5 \mathrm{hmC}$ alterations and mutagenic events in MBs.

\section{Gain-of-5hmC is enriched at regulatory regions of genes involved in stem-like properties}

Recent studies have revealed significant enrichment of $5 \mathrm{hmC}$ at gene bodies of actively transcribed genes in embryonic stem cells (ESCs) and cis-regulatory regions including promoter and enhancer regions [42-45]. Interestingly, gain-of-5hmC was significantly 
enriched at promoter regions $(\log 2$ enrichment $=1.512, p<0.001)$ and transcription start sites $(\log 2$ enrichment $=1.657, p<0.001)$, whereas loss-of-5hmC was enriched at genic regions including exons $(\log 2$ enrichment $=1.146, p<0.001)$ and introns $(\log 2$ enrichment $=0.721, p<0.001$ ), indicating that gain-of-5hmC can play a more active role in gene transcriptional regulation in MBs (Fig. 2b and Additional file 5: Table S4). Notably, $5 \mathrm{hmC}$ signals in tumors were highly enriched at previously reported $\mathrm{MB}$ enhancer regions [46], while those of normal samples were more evenly dispersed across the genome (Fig. 2c). Moreover, motif analysis with Hypergeometric Optimization of Motif EnRichment (HOMER) [47] identified that gain-of-5hmC was enriched at over $40 \%$ of target sequences with Nanog and $\mathrm{Scl}$ (stem cell leukemia) motifs (FDR $<0.05$, Fig. 2d and Additional file 6: Table S5). In mouse ESCs, the physical interaction between NANOG and TET1/TET2 proteins yields an increase in $5 \mathrm{hmC}$ levels at target regions such as Esrrb (estrogen related receptor beta) and Oct4 (octamer-binding transcription factor 4), elevating the expression of key reprogramming genes [48, 49], suggesting that Nanog can contribute to regional $5 \mathrm{hmC}$ formation in MBs. In addition, gain-of-5hmC was highly enriched at other bHLH (basic helix-loop-helix) transcription factors including OLIG2 (oligodendrocyte transcription factor, 20.81\%), NEUROG2 (neurogenin 2, 16.17\%), and ASCL1 (achaete-scute family BHLH transcription factor 1, 13.97\%) (Additional file 6: Table S5), which are involved in neurogenesis and maintenance of stem cell-like properties [50-52]. Gain-of-5hmC was also found in about $15 \%$ of binding sites of LIM homeobox genes (LHX1, LHX2, and LHX3), suggesting that gain-of-5hmC has the potential to regulate super-enhancer regions in MBs [46]. Further functional prediction of cis-regulatory regions using Genomic Regions Enrichment of Annotations Tool (GREAT) identified that gain-of-5hmC was enriched at genes involved in cerebellar development, including netrin-mediated signaling, reelin signaling, and genes involved in axon guidance as well as the Notch signaling pathway (Fig. 2e and Additional file 7: Table S6). To investigate whether DhMRs in MBs are indeed involved in controlling stem-like properties, we compared genome-scale patterns of gain-of$5 \mathrm{hmC}$ and loss-of-5hmC with normal fetal or adult DhMRs that were published previously [53]. Genomic loci containing $5 \mathrm{hmC}$ in fetal samples tended to map to gain-of$5 \mathrm{hmC}$ regions although many $5 \mathrm{hmC}$ regions associated with MBs still overlapped with those of adult samples $\left(R^{2}=0.0893\right.$, FDR $<0.001$, Fig. $\left.2 \mathrm{f}\right)$. In addition, $5 \mathrm{hmC}$ regions from adult substantially mapped to loss-of-5hmC regions $\left(R^{2}=0.6118, \mathrm{FDR}<0.001\right.$, Fig. 2g). Collectively, these results show that $5 \mathrm{hmC}$ patterns in human MBs contain distinct $5 \mathrm{hmC}$ features of both fetal and adult cerebellum, suggesting that tumor cells might coopt or retain fetal epigenomic methylation patterns that promote stemness during tumorigenesis.

\section{The $5 \mathrm{hmC}$ signature of MBs in SmoA1 mice recapitulates that of human MB}

To further explore the role of $5 \mathrm{hmC}$ and TET in $\mathrm{MB}$ progression, we utilized the SmoA1 mouse model, as $5 \mathrm{hmC}$ signatures are not maintained in cell culture mainly due to a drop in TET expression [23,37]. These mice constitutively express active Smo, specifically in granule neuron precursors (GNPs) and are prone to spontaneous MB development in the cerebellum [54, 55]. Consistent with human $\mathrm{MB}$, global 5hmC levels were significantly reduced (Fig. 3a, b and Additional file 1: Fig. S3a) and Tet1 and Tet2 


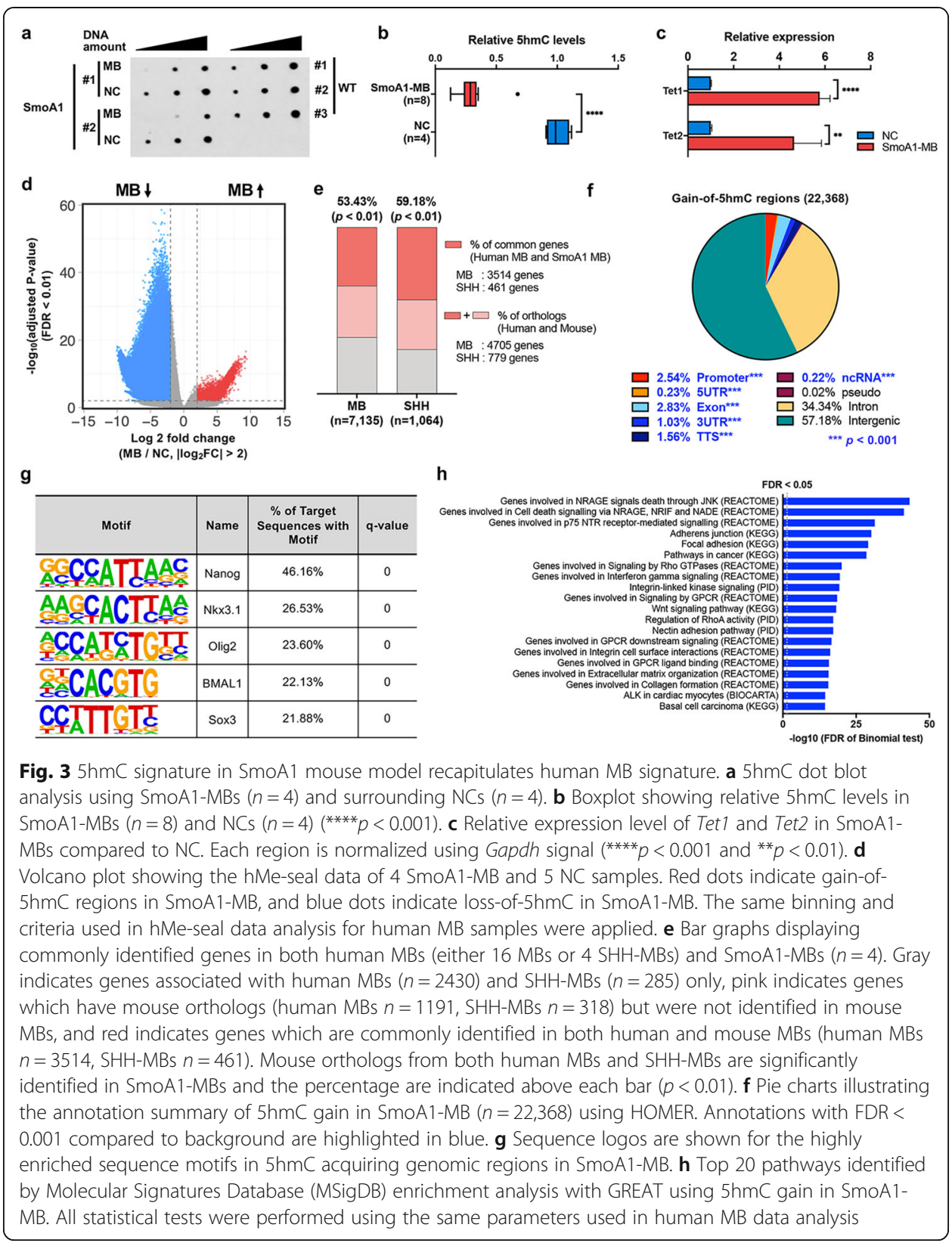

gene expression increased (Fig. 3c) in the transgenic mice tumors, compared to adjacent normal cerebellum. Profiling of the genome-wide $5 \mathrm{hmC}$ distribution in 4 mouse MBs compared to 5 normal cerebellum samples showed distinct patterns in tumors (Additional file 1: Fig. S3), and we identified 22,368 gain-of-5hmC regions and 317,120 loss-of-5hmC regions (Fig. 3d and Additional file 8: Table S7). Next, we looked for similarities between the two species' tumors by comparing the conserved regions of gain-of-5hmC. We performed this analysis using either all human $\mathrm{MB}$ groups combined $(n=16)$ or focusing only on human MBs classified into the SHH subgroup $(n=4)$ since the $\operatorname{SmoA1}$ mouse model was developed to produce mice with a high incidence of Hedgehog $(\mathrm{Hh})$ signaling associated $\mathrm{MBs}$, which mimics SHH-MB patients. We identified an additional 1352 gain-of-5hmC regions in the 4 SHH-MBs 
(Additional file 1: Fig. S3e. We then found conservation rates to the mouse genome using the LiftOver tool (UCSC) with all gain-of-5hmC regions of human MBs and SHH-MBs, which were 99.5\% and 94.0\%, respectively (Additional file 1: Fig. S3 and Additional file 9: Table S8). In total, 21.9\% of the 1257 conserved gain-of- $5 \mathrm{hmC}$ regions of SHH-MBs were commonly identified in gain-of-5hmC regions of SmoA1-MBs (Fisher's exact test $p<0.01$, Additional file 1: Fig. S3e and Additional file 9: Table S8). In addition, a substantial number of the 22,254 conserved gain-of- $5 \mathrm{hmC}$ regions of all human MB groups were detected in gain-of-5hmC regions of SmoA1-MBs; however, the percentage of overlap between all human MBs and SmoA1-MBs was smaller (5.18\%; Fisher's exact test $p<0.01$, Additional file 1: Fig. S3f and Additional file 9: Table S8). Given that the context-dependent $5 \mathrm{hmC}$ signature may not be well conserved between species, and $5 \mathrm{hmC}$ plays a role in gene expression, we also explored how many genes near gain-of-5hmC regions of either human MBs $(n=16)$ or SHH-MBs $(n=4)$ were overlapped with the 9051 genes near gain-of-5hmC regions of SmoA1-MBs (Fig. 3e, Additional file 1: Fig. S3g). Interestingly, 53.43\% of mouse orthologs of genes near gain-of-5hmC regions of all human MBs (mouse orthologs $=4705$, total $=7135$ ) were commonly identified in genes near gain-of-5hmC regions of SmoA1-MBs, which was comparable with the overlapping percentage (59.18\%) of mouse orthologs of genes near gain-of-5hmC regions of SHH-MBs (mouse orthologs = 461, total = 1064) (Fisher's exact test $p<0.01$, Fig. 3e, Additional file 1: Fig. S3g and Additional file 10: Table S9). In addition, we performed similar analyses using loss-of-5hmC regions. Interestingly, we also identified substantial overlap of loss-of- $5 \mathrm{hmC}$ between human $\mathrm{MB}$ and mouse in the genomic level (54.20\%) and gene level (84.43\%) (Additional file 1: Fig. S3h), indicating that both gain-of-5hmC and loss-of-5hmC could be cancer-specific epigenetic marks.

Consistent with human annotation features, gain-of-5hmC regions of SmoA1-MB were enriched at promoter regions $(\log 2$ enrichment $=1.228, p<0.001)$ and transcriptional start sites $(\log 2$ enrichment $=1.764, p<0.001$ ) (Fig. 3f and Additional file 11: Table S10), while loss-of- $5 \mathrm{hmC}$ regions of SmoA1-MB were enriched at intron ( $\log 2$ enrichment $=0.784, p<0.05$ ) and 3'UTR regions ( $\log 2$ enrichment $=0.806, p<0.05$, Additional file 1: Fig. S3i). Motif analysis and functional prediction of cis-regulatory regions using GREAT analysis revealed high concordance with the $5 \mathrm{hmC}$ signature identified in human MBs (Fig. 3g, h, and Additional file 12: Table S11 and Additional file 13: Table S12). Altogether, these data show strong epigenetic similarities between the SmoA1-derived MBs and human MBs, regardless of molecular grouping.

\section{TET1 is a key enzyme in modulating MB progression}

As TET1 and TET2 were consistently overexpressed in both human and murine MBs (Figs. 1e and 3c), we examined whether loss of either may alter the formation and progression of murine MBs. Since mice bearing MBs show distinguishable features including hunched posture and typically die within 2 weeks due to difficulty with eating [54, 55], we investigated onset of medulloblastoma-associated symptoms. Interestingly, crossing $\mathrm{SmoA1}^{+/+}$mice with Tet1 knockout mice led to a dramatic delay in age-ofonset of medulloblastoma-associated symptoms in $\mathrm{SmoAl}^{+/+} ; \mathrm{Tet}^{+/-}$(median survival 18.86 weeks versus undetermined) and a decrease in incidence of $\mathrm{MB}$ (42.7\% versus 
82.2\% at 20 weeks; $p<0.0001$; log-rank test) (Fig. 4a, Additional file 1: Fig. S4a), while no significant effects were observed upon crossing with Tet 2 knockout mice ( $p=$ 0.8435; log-rank test, Fig. 4b, Additional file 1: Fig. S4a). The effect was gene dosagedependent as homozygous loss of Tet1 further reduced penetrance, particularly on a heterozygous SmoA1 background (Additional file 1: Fig. S4b). MBs derived from SmoA $1^{+/+} ;$Tet $^{+/-}$mice showed significantly higher global $5 \mathrm{hmC}$ levels than tumors from $\mathrm{SmoA1}^{+/+}$compared to mice with similar age of disease-related symptoms (Fig. 4c, $\mathrm{d}$ and Additional file 1: Fig. S4c), indicating that TET1 is a major contributor of global $5 \mathrm{hmC}$ depletion found in MBs. We then determined the correlation between TET1 expression and age-of-onset. Consistent with mRNA expression levels, TET1 protein levels were significantly elevated in MBs $(p<0.05$; Fig. 4e) and exhibited a significant inverse correlation with age-of-onset $\left(R^{2}=0.5059, p=0.0366\right.$; Fig. 4f). Histological examination revealed a high incidence of hyperplasia $(<50 \%$ of the cerebellum morphologically abnormal) and invasive tumors ( $>50 \%$ of the cerebellum morphologically abnormal) in 12-week-old $S m o A 1^{+/+}$mice which contained higher Ki67 positive cells (Fig. 4g, Additional file 1: Fig. S4), but we observed normal cerebellar morphology from the majority of $\mathrm{SmoAI}^{+/+}$; $\mathrm{Tet}^{+/-}$mice (Fig. 4g, Additional file 1: Fig. S4d). Immunofluorescence staining data showed TET1 expression is significantly higher in Ki67 positive cells (Fig. 4h). Taken together, these results demonstrate that TET1, not TET2, is a key TET enzyme involved in abnormal proliferation in MB progression.

\section{Inhibition of TET1 expression in MB cells attenuates tumor growth in vitro}

To determine whether abrogation of Tet1 expression attenuates tumor cell growth, we used small hairpin RNA (shRNA) targeting of Tet1 in primary cell cultures of SmoA1MBs. The knockdown was specific to Tet 1 and resulted in a 50\% decrease in cell viability (Fig. 5a, b), while the overexpression of TET1 rescued the knockdown phenotype (Additional file 1: Fig. S5a, b). To further investigate whether pharmacological inhibition of TET1 could also have the same impact on MB cells, we used UC-514321, a small molecule that suppresses the expression of Tet 1 by inhibiting binding of STAT (signal transducer and activator of transcription) transcription factors (STAT3 and STAT5) at Tet1 promoter regions [56]. SmoA1-derived MBs showed higher expression of STAT3 as well as higher levels of phosphorylated STAT3 while STAT5 level was slightly increased (Additional file 1: Fig. S5c, d, e), implying that STAT transcription factors may be a major contributor to Tet1 upregulation in MBs. Consistent with shRNA-mediated Tet1 inhibition, we observed a dose-dependent cytotoxic effect of the inhibitor in primary cell cultures of SmoA1-MBs, but not in normal neuronal stem cells (NSCs) (Fig. 5c, d and Additional file 1: Fig. S5f), indicating that this inhibitor can selectively induce cell death of tumors. The pharmacological benefit of UC-514321 observed in SmoA1-MBs was also reproduced in human MB cell lines (Fig. 5e, $\mathrm{f}$ and Additional file 1: Fig. S5f). Notably, only TET1-expressing lines (Daoy, ONS-76, and D556) were responsive to the inhibitor; no effect was seen in the non-TET1-expressing line (D425) (Fig. 5e, f and Additional file 1: Fig. S5g). To further investigate which genes and signaling pathways were significantly altered upon inhibitor treatment, we performed RNA-seq analysis (Fig. 5g). Intriguingly, mitogen-activated protein kinases (Mapk3, Mapk8, and Mapk7) and phosphoinositide 3-kinases (Pik3cg) were 


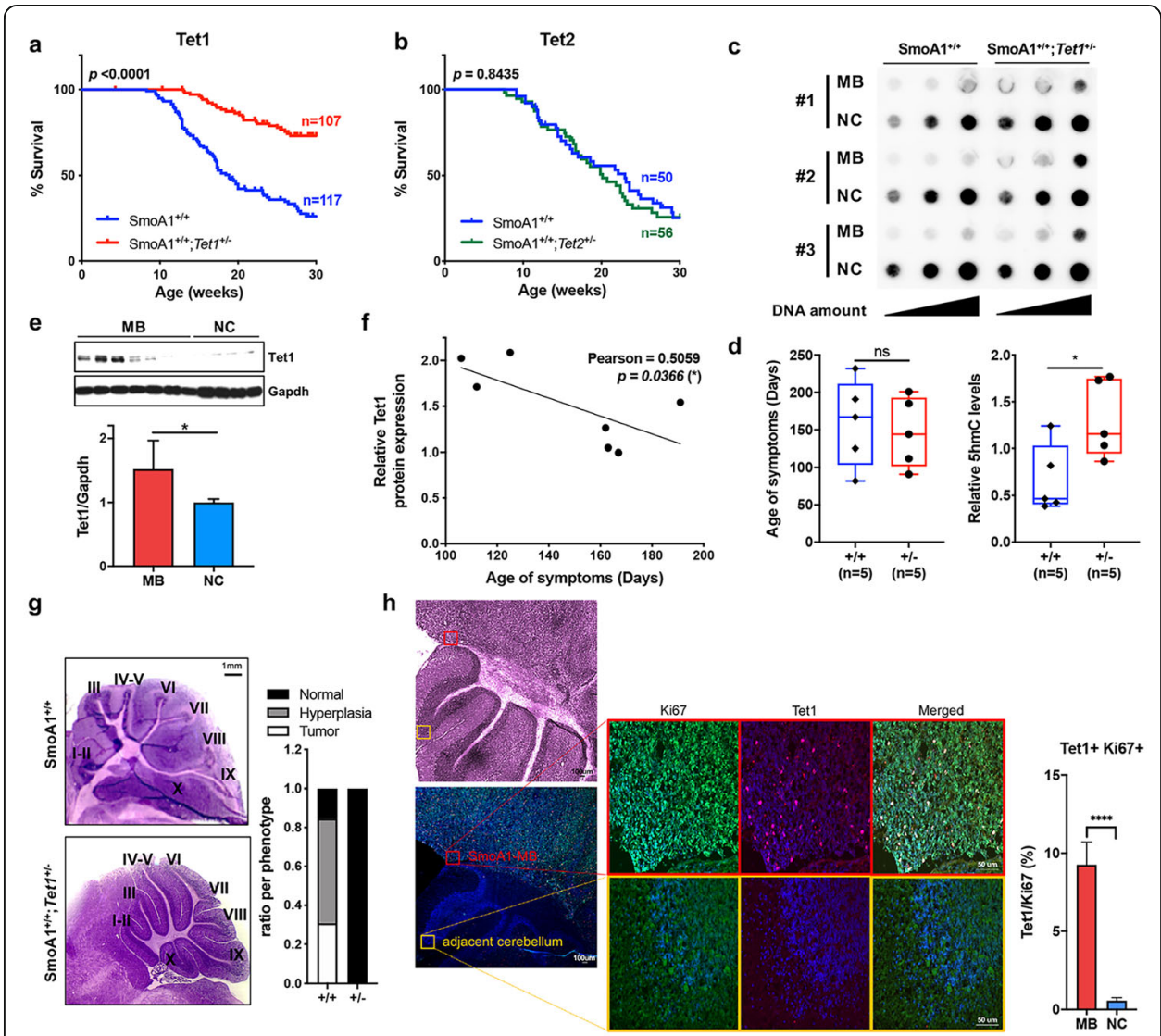

Fig. 4 Elevated Tet1 is essential for MB progression. a, b Kaplan-Meier curves show the significant increase in survival from SmoA1 $1^{+/+}$mice crossed with hemizygous deletion of Tet1 (a $p<0.0001$; log-rank test), but not crossed with hemizygous deletion of Tet2 ( $\mathbf{b} p=0.5830$; log-rank test). $\mathbf{c}$, $\mathbf{d} 5 \mathrm{hmC}$ dot blot analysis shows significant increase in $5 \mathrm{hmC}$ levels in tumors from SmoA $1^{+/+} ; \mathrm{Tet}^{+/-}$mice $(n=5 ; 3$ representative samples shown) compared to tumors from $\mathrm{SmoA}^{+/+}(n=5 ; 3$ representative samples shown) despite similar ages of tumor-associated symptoms shown in box plot below dot blot ( $n=5$ per group). e Tet1 protein expression is significantly higher in SmoA1-MBs $(n=7)$ compared to corresponding NCs $(n=4)(p<$ 0.05). $\mathbf{f}$ Pearson correlation between Tet1 expression and age-of-onset (Pearson $R^{2}=0.5059,{ }^{*} p=0.0366$ ). $\mathbf{g}$ H\&E staining (left) and ratio per phenotype (right) of 12-week-old SmoA ${ }^{+/+}$mice in the presence of either wild-type or hemizygous deletion of Tet1 ( $p<0.0001$; Welch's $t$-test). $\mathbf{h}$ Fluorescence microscopy of normal cerebellum and MB with Ki67 (red) and Tet1 (green) in 12-week-old SmoA $1^{+/+}$mice showing Tet1 expression is significantly higher in Ki67-positive cells (blue: DAPI, ${ }^{* * *} p<0.001$ )

significantly downregulated with the TET1 inhibitor treatment (Fig. $5 \mathrm{~h}$ and Additional file 14: Table S13), and PANTHER pathway analysis identified significant enrichment of PDGF signaling pathway (Fig. 5i). Both shRNA treatment and TET1 inhibitor data indicate that targeting Tet1 has the potential to suppress MB growth.

\section{TET1 contributes to Pdgfr upregulation through interacting with Nanog}

Substantial enrichment of gain-of-5hmC at NANOG binding sites was identified in both human and murine MBs (48.84\% and $46.16 \%$, respectively), and NANOG is a known binding partner of TET1 in the mouse ESCs [48, 49]. We also detected an interaction between TET1 and NANOG in mouse SmoA1-MBs (Fig. 6a). Therefore, we performed a meta-analysis of previously identified genomic regions bound by both NANOG and TET1 [48] and our hMe-seal sequencing and RNA-sequencing data. We 


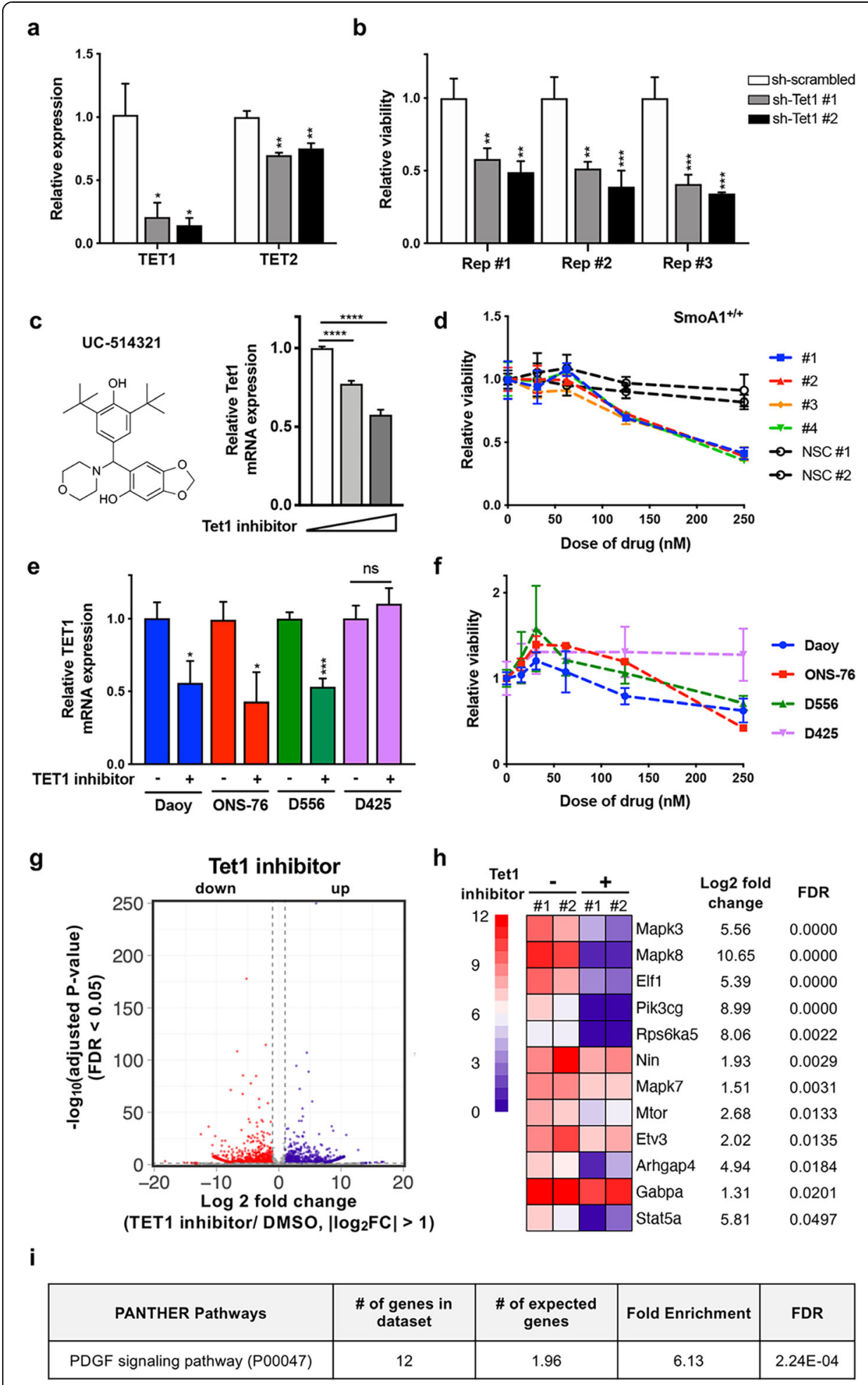

Fig. 5 (See legend on next page.) 
(See figure on previous page.)

Fig. 5 TET1 inhibition confers cytotoxic effect on both SmoA1- and human MBs. a mRNA Tet1 and Tet2 expression upon shRNA treatment targeting Tet1 in primary cultures of SmoA1-MBs. Expression was normalized with Gapdh expression (* indicates $p<0.05$ and ** indicates $p<0.01$ ). b Relative cell viability in 5 days of two different sh-Tet1-treated primary cells compared to sh-scrambled-treated primary cells for three biological replicates (** indicates $p<0.01$ and ${ }^{* * *}$ indicates $\left.p<0.001\right)$. c Left: structure of TET1 inhibitor UC-514321. Right: dose-dependent expression of Tet1 2 days after chemical treatment $(0 \mathrm{nM}, 100$ $\mathrm{nM}$, and $200 \mathrm{nM}$, respectively, $p<0.0001$ for both). d Relative cell viability depending on dose of drug ( $\mathrm{nM}$ ) in SmoA $1^{+/+}$. NSC: Neuronal stem cell. e mRNA Tet1 expression upon $200 \mathrm{nM}$ of UC-514321 treatment in MB cell lines, including Daoy ( $p<0.05)$, ONS-76 ( $p<0.05)$, D556 ( $p<0.001)$, and D425 (no significance). $\mathbf{f}$ Relative cell viability depending on dose of drug $(n M)$ in MB cell lines. $\mathbf{g}$ Volcano plot showing RNA-seq data of 2 DMSO-treated and drug-treated primary cultures of SmoA1-MBs. Purple dots indicate upregulated transcripts, and red dots indicate downregulated transcripts 2 days after TET1 inhibitor treatment. Transcripts with absolute fold change $>2$ and adjusted $p$ value $<0.05$ are considered statistically significant. $\mathbf{h}$ Genes significantly downregulated after TET1 inhibitor treatment (absolute fold change $>2$ and FDR $<0.05$ ). i PANT HER pathway analysis using downregulated genes after TET1 inhibitor treatment

first identified the DhMRs which are located at binding regions of both TET1 and NANOG (Fig. 6b), and selected the regions located at promoter-TSS regions (Fig. 6b and Additional file 15: Table S14). In total, 71 gain-of-5hmC regions (corresponding to 70 unique genes) and 266 loss-of-5hmC regions (corresponding to 227 unique genes) were identified in MB DhMRs (Additional file 15: Table S14). We then examined gene expression changes in 297 identified genes and identified eight genes (Btg3, Ccnd3, Dram1, Fgf8, Mmp14, Pdgfra, Pdgfrb, and Sept9) which had higher 5hmC signals at their promoter regions and showed higher expression in SmoA1-MBs (Fig. 6c, d). Among these eight genes, genomic alterations in Ccnd3, Pdgfra, Pdgfrb, and Sept9 are known for their implication in tumorigenesis in multiple cancer types [60]. PDGFR subunits - a and -b are well-known cell surface tyrosine kinase receptors implicated in cell proliferation, growth, and development. In metastatic MBs, both PDGFRs are highly overexpressed compared to non-metastatic tumors and are involved in the regulation of genes in the RAS/MAPK signal transduction pathway [61, 62]. We performed a chromatin immunoprecipitation (ChIP) assay using SmoA1-MB and found that TET1 could bind to the regulatory region of either Pdgfra or Pdgfrb where $5 \mathrm{hmC}$ levels are significantly elevated (Fig. 6e and Additional file 1: Fig. S5h). Interestingly, some of TET1 binding overlapped with NANOG binding, suggesting that NANOG, which interacts with TET1 in SmoA1-MB, can bind to the same regions along with TET1. To further determine whether the inhibition of Tet1 expression leads to a decrease in Pdgfra and Pdgfrb expression, we treated primary cell cultures of SmoA1-MBs with the TET1 inhibitor and identified that both Pdgfra and Pdgfrb were downregulated (Fig. 6f). In summary, these data indicate that PDGFRs are downstream targets of TET1 and NANOG, their expression can be regulated by a TET1 inhibitor, and thus, TET1 is a potential therapeutic target to treat TET1-overexpressing MBs.

\section{Discussion}

MBs, the most aggressive pediatric brain tumors, can be subdivided into four molecular groups based on transcriptome and methylation profiling: WNT, SHH, Group 3, and Group 4 [63]. Recent studies, however, have demonstrated that the current molecular grouping is insufficient to predict patients' prognosis. For instance, tumor protein P53 (TP53) mutation is a critical risk factor in both WNT and SHH-MB subgroups [64]. In 


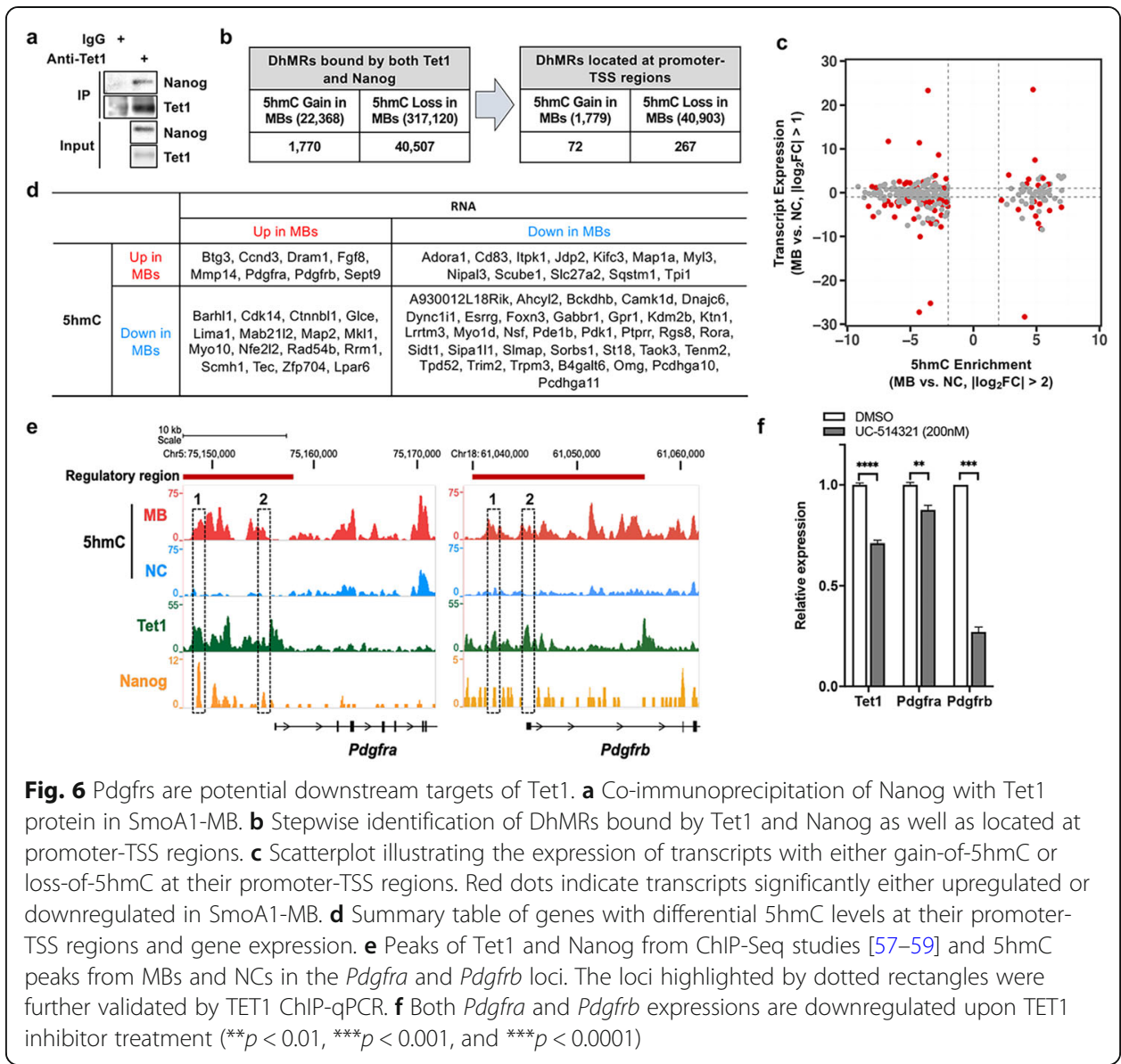

addition, aberrant DNA methylation at the genes involved in embryonic morphogenesis is also considered as a potential driver of the oncogenic process in the SHH subgroup diagnosed after 5 years of age $\left(\mathrm{MB}_{\mathrm{SHH}-\mathrm{Children}}\right)$ [65]. Since loss of $5 \mathrm{hmC}$, the first oxidative derivative of $5 \mathrm{mC}$, has served as an unfavorable indicator for several malignant tumors (e.g., high-grade glioma (GBM) and melanoma [13, 66]), we investigated alteration of $5 \mathrm{hmC}$ in $\mathrm{MB}$. Consistent with prior findings in other tumor types, we have identified a significant reduction in $5 \mathrm{hmC}$ across $\mathrm{MB}$ genomes and a strong inverse correlation between $5 \mathrm{hmC}$ levels and prognosis. Importantly, we identified the enrichment of an MB-specific 5hmC signature at NANOG, a key transcription factor involved in self-renewal and pluripotency of ESCs. NANOG is overexpressed in MBs, which prevents differentiation and maintains stemness of tumors [67]. Moreover, compared to normal tissues, $5 \mathrm{hmC}$ signals in MBs were higher at the MB active enhancers of cisacting transcription activating elements, suggesting that $5 \mathrm{hmC}$ plays a critical role in regulating MB-associated gene expression. We also identified that gain-of-5hmC regions were involved in the activation of embryonic development signaling pathways such as the Notch signaling pathway. The activation of Notch signaling not only induces expression of stem-like markers and cell growth in tumors but also confers drug resistance through multidrug resistance $\mathrm{ABC}$ (ATP-binding cassette) transporters [68, 
69]. Indeed, the resemblance of gain-of- $5 \mathrm{hmC}$ regions to fetal $5 \mathrm{hmC}$ patterns indicates that gain-of-5hmC plays a critical role in maintaining stem cell-like properties in MBs.

Ten-eleven translocation (TET) enzymes (TET1, TET2, and TET3) are $\alpha$ ketoglutarate-dependent dioxygenases that convert $5 \mathrm{mC}$ to $5 \mathrm{hmC}[70,71]$, and therefore, their expression tends to be strongly correlated with $5 \mathrm{hmC}$ levels. Indeed, the overexpression of TET2 in melanoma cells suppresses tumor initiation and progression by increasing $5 \mathrm{hmC}$ levels [72], and elevated $5 \mathrm{hmC}$ by upregulated TET1 recruits the CHOIP-methylosome complex near the genes involved in glioblastomagenesis [73]. Surprisingly, we observed an overall loss of $5 \mathrm{hmC}$ and elevated TET1 and TET2 in clinical MB samples. Given the frequent identification of TET loss of function mutations along with global hypomethylation, regional hypermethylation in cancer, and the redundant actions of TET proteins in terms of $5 \mathrm{hmC}$ formation [74, 75], the abnormal expression of TET proteins may not always show correlation with global $5 \mathrm{hmC}$ levels. In addition, when crossing $T e t 1^{+/-}$mice with the $\operatorname{SmoA1}$ mouse model, which has a high incidence of spontaneous $\mathrm{MB}$ development, we found a dramatic decrease in tumor incidence and tumor onset while the abolishment of Tet2 did not change tumor incidence and age-of-onset. In addition, shRNA- and chemically mediated downregulation of Tet1 promoted cell death in both murine and human tumors. Further investigation identified Pdgfra and Pdgfrb as potential downstream targets regulated by TET1 and NANOG. The regulatory regions of Pdgfra and Pdgfrb are not only binding sites for TET1 and NANOG, but also show high levels of $5 \mathrm{hmC}$ in MBs compared to NCs. In addition, a TET1 inhibitor significantly decreased Pdgfrs' expression. Although additional investigation is needed to determine whether TET1 is a bona fide oncoprotein in MB tumorigenesis and whether overexpressed TET2 is cooperative with TET1 to establish global $5 \mathrm{hmC}$ level during $\mathrm{MB}$ tumorigenesis, our genetic studies demonstrate that TET1 modulates MB tumorigenesis by tumor-specific $5 \mathrm{hmC}$ formation along with NANOG. In addition, further investigation to demonstrate the relationship of overexpressed TET1 and tumor-specific $5 \mathrm{hmC}$ signature is needed.

\section{Conclusions}

We present the first comprehensive genome-wide profiling of $5 \mathrm{hmC}$ and its role in maintaining stemness in $\mathrm{MB}$ tumorigenesis. We also identify TET1 as a heretofore unknown $\mathrm{MB}$ oncogene and its role in tumor formation. Our data further show that small molecule-mediated suppression of TET1 can be a therapeutic option for MB subgroups having highly expressed TET1. These findings provide an insight into a new epigenetic driver, "epi-driver," in pediatric brain tumor and the biological importance of the driver in tumor-associated signaling pathway.

\section{Methods}

All experimental methods comply with the Helsinki declaration.

\section{Human tissues}

Medulloblastoma (MB) samples were collected from three different sources: Aflac cancer center $(n=5)$, the Xiangya Hospital Department of Neurosurgery $(n=24)$, and Dr. Erwin G. Van Meir $(n=8)$. UHPLC-MS/MS assay used in Fig. 1a and Additional file 1 
included $24 \mathrm{MB}$ samples from the Xiangya Hospital and $5 \mathrm{MB}$ samples from Aflac cancer center. For $5 \mathrm{hmC}$ profiling in Figs. 2 and 3, MB samples from Xiangya, $5 \mathrm{MB}$ samples from Aflac cancer center, and $8 \mathrm{MB}$ samples from Dr. Erwin G. Van Meir were used. The patient data was anonymized prior to use in this study. For MB tissue samples from Aflac cancer center, molecular subgroup affiliation was determined by NanoString nCounter system using $22 \mathrm{MB}$ subgroup-specific gene expression profiles. The protocols were approved by the Institutional Review Board at Emory University. Twenty-four MB tissue samples range from 3 to 18 years old with average-risk (children older than 3 years of age with no evidence of metastatic disease and less than $1.5 \mathrm{~cm}^{3}$ of residual disease) were collected at the Department of Neurosurgery of Xiangya Hospital. All participants or their legal guardians enrolled in this study provided informed consent. Five normal cerebellum samples used in Fig. 1a as normal control for dot blot assay were collected from patients from 3 to 18 years old with cerebral injury who underwent internal decompression. Six normal cerebellum samples from 5 to 19 years old with no neurological disorders were collected from the NIH NeuroBioBank tissue repositories, which were used as normal control for the dot blot assay (Additional file 1: Fig. S1) and genome-wide 5hmC profiling (Fig. 2).

\section{Mice}

All protocols for mouse experiments were approved by the Institutional Animal Care and Use Committee (IACUC) at Emory University. $\operatorname{Tet}^{+/-}$and $\mathrm{Tet}^{+/-}$mice $[76,77]$ were initially on a mixed C57BL/6x129S4/Sv background and were backcrossed with WT C57BL/6 mice for more than 10 generations before any of the experiments in this paper. SmoA1 homozygous mice [55] were crossed with either $\mathrm{Tet}^{+/-}$mice or $\mathrm{Tet}^{+{ }^{+-}}$ to generate cohorts in this study. Mice were humanely euthanized using isoflurane inhalation upon the signs of disease-related symptoms.

\section{Primary MB culture}

Mice were euthanized by isoflurane inhalation when they showed disease-associated symptoms including hunched posture, tilted head, and lethargy. Isolated tumor tissues were minced in sterile HBSS to obtain a single-cell suspension. To remove cell aggregates and extraneous tissue, the suspension was passed through two different size cell strainers $(100 \mu \mathrm{m}$ and $40 \mu \mathrm{m})$ and spun down to collect a cell pellet. The cell pellet was resuspended in Neurobasal medium supplemented with B-27 supplements, L-glutamine, sodium pyruvate, and Pen/Strep and plated at $1.5 \times 10^{6}$ cells per well in a 24 -well plate on Matrigel-coated wells. For shRNA-Tet1 treatment, wells were infected with lentivirus at a multiplicity of infection (MOI) of 10 and incubated for 5 days. For TET1 inhibitor (UC-51432) treatment [56], wells were incubated with appropriate concentration of the chemical for $48 \mathrm{~h}$.

\section{Human MB cell line culture}

Human MB cell lines (ONS-76, Daoy, D556, and D425) were cultured with DMEM with $10 \%$ fetal bovine serum, $100 \mathrm{U} / \mathrm{ml}$ penicillin, and $100 \mathrm{mg} / \mathrm{ml}$ streptomycin at $37^{\circ} \mathrm{C}$ in an atmosphere of $5 \% \mathrm{CO}_{2}$. 


\section{Analysis of gene expression Array datasets}

Gene expression data of 273 human MB samples and 31 human cerebellar tissue samples were obtained from GEO Series accession numbers GSE49243, GSE12992, GSE10327, GSE37418, GSE50161, GSE44971, GSE7307, and GSE3526. Data analyses were performed using the Bioconductor package "simpleaffy" [78]. Briefly, data were normalized using the gcrma algorithm, and then, molecular subgroups of tumor samples unclassified in the previous studies were determined by unsupervised hierarchical clustering based on 1-Pearson correlation. Differential gene expression analysis was performed using the Bioconductor package "limma" [79], and then, volcano plots and boxplots were generated using the Bioconductor package "ggplot2" [80].

\section{Genomic DNA preparation and dot blot assay}

Genomic DNA preparation and the dot blot assay of $5 \mathrm{hmC}$ were performed as described previously [53]. DNA purification was performed by phenol-chloroform precipitation and reconstituted in DNase-free water.

\section{UHPLC-MRM-MS/MS analysis}

Genomic DNA was enzymatically digested into single nucleosides by a mixture of DNase I, calf intestinal phosphatase, and snake venom phosphodiesterase $\mathrm{I}$ at $37^{\circ} \mathrm{C}$ for $12 \mathrm{~h}$. After the enzymes were removed by ultrafiltration, the digested DNA was subjected to UHPLC-MS/MS analysis. The UHPLC-MS/MS analysis was performed on an ultra-high-performance LC system coupled with a QQQ6490 mass spectrometer equipped with a jetstream electrospray ionization source (Agilent, Santa Clara, CA). A reverse-phase Zorbax SB-C18 column $(2.1 \times 50 \mathrm{~mm}, 1.8-\mu \mathrm{m}$ particles $)$ was used for UHPLC separation. The mass spectrometer was operated under positive ionization using multiple reactions monitoring (MRM) mode. All the quantification data are included in Table S15.

\section{Survival analysis using human samples and mouse model}

Survival was measured from the time of initial diagnosis until the date of death due to progression of disease. The survival distribution was estimated using Kaplan-Meier curves. Survival curves were compared by means of the log-rank test. Results were considered statistically significant when the $p$ value of the log-rank (Mantel-Cox) test was below 0.01 .

\section{Genome-wide $5 \mathrm{hmC}$ profiling (hMe-seal sequencing)}

Tumor tissues and matched normal cerebellar tissues were used for hMe-Seal sequencing $[10,81]$ to identify differential hydroxymethylation regions (DhMRs). For labeling of $5 \mathrm{hmC}$-containing genomic regions, $1 \mu \mathrm{g}$ of sonicated genomic DNA (100-300 bp) was incubated for $2 \mathrm{~h}$ at $37^{\circ} \mathrm{C}$ in a $30 \mu \mathrm{l}$ solution containing $100 \mu \mathrm{M}$ UDP-6-N $\mathrm{N}_{3}$-Glu, $\beta$ glucosyltransferase $(\beta-G T)$ and NEB buffer 4. After purification using AMPure XP beads, $\mathrm{N}_{3}$-glucose-labeled DNA was incubated for $2 \mathrm{~h}$ at $37^{\circ} \mathrm{C}$ with the addition of $150 \mu \mathrm{M}$ dibenzocyclooctyne-modified biotin (click chemistry), and then purified using AMPure XP beads. DNA libraries were generated using NEBNext ${ }^{\oplus}$ Ultra $^{\text {тм }}$ II DNA Library Prep Kit, which were then ready for sequencing. 


\section{Analysis of hMe-seal sequencing data to identify DhMRs}

Sequencing data were mapped to either human genome, hg19, for human medulloblastoma and age-matched normal cerebella or mouse genome, mm10, for SmoA1 medulloblastoma using bowtie2 [82]. Mapped reads were filtered and sorted using SAMtools [83] and then PCR duplicates were removed using Picard [84]. Binned matrices (bin size $2 \mathrm{~kb}$ ) were generated using final bam files, and bins of $\mathrm{MB}$ samples were adjusted with average of relative $5 \mathrm{hmC}$ levels $(0.4367$ for human MBs and 0.3148 for SmoA1MBs). Differential hydroxymethylation regions (DhMRs) were identified using DESeq2 with default parameters [40]. FDR $<0.01$ and $\log 2$ fold change $>2$ were considered as a statistical significance. Identified DhMRs were annotated using Homer [47] and CEAS [85]. To understand the biological meaning of DhMRs, we used GREAT with default "Basal plus extension" settings [86]. Enrichment terms with FDR $<0.05$ (both regionbased binomial and hypergeometric tests) were regarded as statistically significant. For motif scanning on DhMRs and TET1 binding sites, we used Homer software. To understand the similarity between human MBs and SmoA1-MBs, we compared gainof-5hmC regions as well as genes near identified gain-of-5hmC regions. For common region identification, human gain-of-5hmC regions (hg19) were converted to mouse gain-of-5hmC regions ( $\mathrm{mm} 10$ ) using batch coordinate conversion (liftOver), and then common gain-of-5hmC regions were identified using intersectBed (bedtools). For common gene identification, mouse orthologs corresponding to human genes near human gain-of-5hmC regions were identified using BioMart and then compared with genes near mouse gain-of-5hmC regions. Fisher's exact was used to test whether observed number of peaks or genes is greater than expected for statistical significance.

\section{Immunoblotting}

Tumor and matched normal tissues were collected from euthanized SmoA1 mice with MB-associated symptoms. Tissues were rinsed with ice-cold PBS, homogenized after the addition of radioimmuno-precipitation assay (RIPA) buffer supplemented with protease inhibitor cocktail. After incubation on ice for $20 \mathrm{~min}$, lysates were then centrifuged in a microfuge at 13,000 rpm for $15 \mathrm{~min}$, supernatants were quantified using bicinchoninic acid (BCA) assay, and $50 \mu \mathrm{g}$ of each sample was loaded in acrylamide gels for TET1, p-STAT3, STAT3, STAT5a, and GAPDH detection. All immunoblotting was repeated at least three times. For quantitative analysis, autoradiographic films were scanned with an Epson 1680 scanner, and the captured image was analyzed with NIH ImageJ software.

\section{Brain transcardiac perfusion and histology}

For histological analysis, 12-week-old mice from different genotype backgrounds were trans-cardially perfused with $4 \%$ paraformaldehyde in PBS. Brains collected were postfixed with $2 \%$ paraformaldehyde in PBS overnight, cryoprotected in $20 \%$, then $30 \%$ (w/ v) sucrose in $\mathrm{PBS}$ at $4{ }^{\circ} \mathrm{C}$, and rapidly frozen. Cryostat sections $(10 \mu \mathrm{m})$ were stained with hematoxylin and eosin according to the previous Cold Spring Harbor protocol [87]. For immunofluorescent staining, Ki67 (Thermo; 14-5698-82) and TET1 (Genetex; GT1462) antibodies were incubated shaking gently in staining solution ( $0.5 \%$ Triton X- 
100, 5\% normal goat serum, phosphate-buffered saline) at $4{ }^{\circ} \mathrm{C}$ and Alexa fluor 488 and 568 were used as secondary antibodies, respectively.

\section{RNA extraction and RT-PCR}

RNA was extracted from pellets using Trizol reagent (Thermo Fisher Scientific) according to the manufacturer's procedure. After Nanodrop quantification of RNA, $1 \mu \mathrm{g}$ RNA was used to generate cDNA with SuperScript III First-Strand Synthesis System for RTPCR. Quantitative PCR for mRNA of Tet1 and Pdgfra, and proper internal control (GAPDH for Mouse and Actin for Human) detection was carried out using SYBR green (Thermo Fisher Scientific) and a 7500 Fast Real-Time PCR machine (Applied Biosystems) with an initial denaturing step at $95^{\circ} \mathrm{C}$ for $10 \mathrm{~min}$, then 40 cycles of PCR $\left(95^{\circ} \mathrm{C}\right.$ for $15 \mathrm{~s}, 60^{\circ} \mathrm{C}$ for $1 \mathrm{~min}$ ) and a further extension at $60^{\circ} \mathrm{C}$ for $10 \mathrm{~min}$. Specific primer sequences are listed in key resources table.

\section{Proliferation assay}

To assess cell viability after treatment of shRNA and TET1 inhibitor, the CellTiter-Blue Cell Viability Assay (Promega) was used. Briefly, $20 \mu \mathrm{l}$ of solution was added directly to each well $1 \mathrm{~h}$ before measurement. The fluorescence was measured using FLUOstar Omega (BMG Labtech) microplate reader. All measurements were taken in triplicate and each experiment was replicated at least three times.

\section{Analysis of RNA-sequencing data}

RNA for sequencing was prepared using Trizol Reagent from primary MB cells treated by either DMSO (control) or TET1 inhibitor (Drug) for $48 \mathrm{~h}$. Raw sequencing data were mapped to mm10 using HiSAT2 and annotated using StringTie [88]. After the identification of gene-level differentially expressed genes using DESeq2 [40], the TPM (transcripts per kilobase million) value of each sample was plotted to make a chart with software GraphPad Prism 8.0 (GraphPad, Inc.). To understand pathway enrichment of differentially expressed genes, PANTHER pathway analysis $[89,90]$ was performed and $p<0.05$ was considered as a statistical significance.

\section{Co-immunoprecipitation}

For co-immunoprecipitation assays, tumor tissues were lysed through brief sonication on ice in lysis buffer $(20 \mathrm{mM}$ Tris, $\mathrm{pH} 7.4,150 \mathrm{mM} \mathrm{NaCl}, 0.5 \%$ Triton X-100, $1 \mathrm{mM}$ EDTA, $10 \%$ glycerol, $1 \mathrm{mM}$ phenylmethylsulfonyl fluoride, $10 \mu \mathrm{g} / \mathrm{ml}$ aprotinin, $10 \mu \mathrm{g} / \mathrm{ml}$ leupeptin, $1 \mathrm{mM}$ sodium fluoride, $1 \mathrm{mM}$ sodium orthovanadate, and $25 \mathrm{mM} \beta$ glycerophosphate), and then centrifuged at $4{ }^{\circ} \mathrm{C}$ at maximum speed for $10 \mathrm{~min}$. One milligram of the supernatant was then incubated with anti-Tet1 (GeneTex) or control IgG overnight at $4{ }^{\circ} \mathrm{C}$ with rotation, followed by further incubation with Protein-G beads (Pierce) for $4 \mathrm{~h}$ at $4{ }^{\circ} \mathrm{C}$. The following immunoblotting assays were carried out to detect the target proteins as indicated.

\section{Chromatin Immunoprecipitation (ChIP)}

SmoA1-MBs were treated with $1 \%$ formaldehyde for $10 \mathrm{~min}$ at room temperature with gentle shaking. Fixation was terminated by adding $2 \mathrm{M}$ fresh glycine to reach a $0.125 \mathrm{M}$ 
final concentration, and then shaking continued for an additional $5 \mathrm{~min}$. The cell pellet was collected by spinning down at $3750 \mathrm{rpm}$ for $10 \mathrm{~min}$ at $4{ }^{\circ} \mathrm{C}$. The cell pellet was then resuspended in $1 \mathrm{~mL}$ Nuclei Swelling Buffer (10 mM HEPES/pH 7.9, 0.5\% NP-40, 1.5 $\mathrm{mM} \mathrm{MgCl} 2,10 \mathrm{mM} \mathrm{KCl}, 0.5 \mathrm{mM} \mathrm{DTT}$, and protease inhibitor cocktail), incubated on ice for $10 \mathrm{~min}$, and centrifuged at $5000 \mathrm{rpm}$ for $5 \mathrm{~min}$. Nuclear pellets were further lysed in $200 \mathrm{ml}$ SDS lysis buffer (20 mM HEPES/pH 7.9, 25\% glycerol, 0.5\% NP-40, $0.5 \%$ Triton X-100, $0.42 \mathrm{M} \mathrm{NaCl}, 1.5 \mathrm{mM} \mathrm{MgCl}_{2}, 0.2 \mathrm{mM}$ EDTA), and protease inhibitor cocktail. Cell lysate was sonicated 8 times with 0-3 Power Output for $30 \mathrm{~s}$ each (at least $30 \mathrm{~s}$ cooling on ice between each $30 \mathrm{~s}$ sonication) to obtain DNA fragments between 200 and $500 \mathrm{bp}$. After sonication, nuclear lysate was cleared by centrifugation at $13,000 \mathrm{rpm}$ for $10 \mathrm{~min}$ at $4{ }^{\circ} \mathrm{C}$ to collect the supernatant. The nuclear lysate was diluted with 4 volumes of dilution buffer (0.01\% SDS, 1\% Triton X-100, 1.2 mM EDTA, 167 $\mathrm{mM} \mathrm{NaCl}, 16.7 \mathrm{mM}$ Tris- $\mathrm{HCl} / \mathrm{pH}$ 8.0, and protease inhibitor cocktail). Diluted nuclear lysate was pre-cleared by $30 \mathrm{ml}$ pre-washed Protein-G Dynabeads (Thermo Fisher, cat\# 10009D) for $2 \mathrm{~h}$ at $4{ }^{\circ} \mathrm{C}$. After pre-clear, immunoprecipitation was performed with TET1 antibody (GeneTex, GTX627420) with overnight rotation at $4{ }^{\circ} \mathrm{C}$. Thirty milliliters pre-washed Protein-G Dynabeads (Thermo Fisher, cat\# 10009D) were added for an additional $2 \mathrm{~h}$. The beads were then washed and eluted. The ChIPed DNA fragments were purified using QIAquick PCR Purification Kit (QIAGEN, cat\#28106). ChIPed DNA and input DNA was used for qPCR.

\section{Meta-analysis to identify genes potentially regulated by TET1}

DhMRs bound by TET1 and NANOG as well as located at promoter-TSS regions were identified by two steps: first, TET1- and NANOG-bound DhMRs were detected via intersectBed [91], and then, DhMRs were annotated using HOMER. Total RNA for sequencing was prepared using Trizol Reagent from primary SmoA1-MB tissues and adjacent normal cerebella $(\mathrm{NC})$ followed by data analysis pipeline used for RNA-seq data analysis with drug-treated MB primary cells.

\section{Supplementary Information}

Supplementary information accompanies this paper at https://doi.org/10.1186/s13059-021-02352-9.

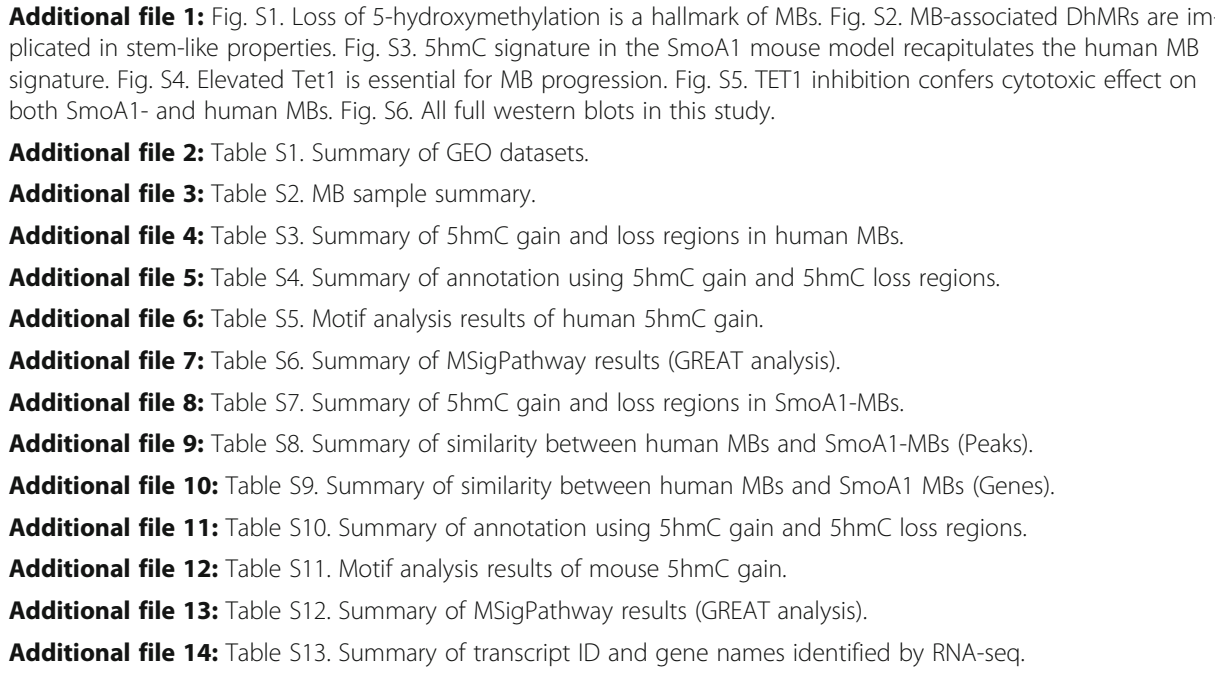


Additional file 15: Table S14. DhMRs bound by both Tet1 and Nanog.

Additional file 16: Table S15. Summary of $5 \mathrm{hmdC}$ and $\mathrm{dC}$ in human normal cerebella $(n=5)$ and human MBs $(n=24)$.

Additional file 17: Table S16. Summary of all the key reagents.

Additional file 18. Review history

\section{Acknowledgements}

We are grateful to $\mathrm{NIH}$ NeuroBioBank for providing frozen human brain tissues specimens.

\section{Review history}

The review history is available as Additional file 18.

\section{Peer review information}

Anahita Bishop was the primary editor of this article and managed its editorial process and peer review in collaboration with the rest of the editorial team.

\section{Authors' contributions}

J. L. and P. J. conceived the study. H.K., J. L., and P.J. wrote the manuscript. H.K. and Y.K. performed most of the experiments and data analysis. Y.L. and L.L. established hMe-seal sequencing and library preparation for this study. L.C., N.J., B.G.B, Q.S., K.N.C., and P.M.V. contributed to data analysis. M.H.R. and A.M.K. provided SmoA1 mouse model and SmoA1-MB and NC samples and X.Y., X.L., J.Z. Z.Z., R.C.C., D.Z., and E.G.V.M. provided human MB samples for this study. All of the authors read and commented on the manuscript. The author(s) read and approved the final manuscript.

\section{Funding}

This research was supported in part by National Institute of Health (NS079625 to PJ, CA235162 and NS096236 to EGVM), Winship Invest\$ pilot grant (P30CA138292 to PJ), National Natural Science Foundation of China (No. 81902551) and the CURE Childhood Cancer Foundation (to EGVM).

\section{Availability of data and materials}

Sequencing data have been deposited to GEO with accession number GSE74336 [92] including hMe-seal results for 3 human MB samples and 1 normal sample and the NCBI Sequence Read Archive (SRA) under accession number PRJNA554937 [93] including hMe-seal results for 26 human MBs, 12 NCs, 8 SmoA1-MBs, and 6 NCs, and RNA-seq result for 8 SmoA1-MBs. Human gene expression data were obtained from GEO Series accession numbers GSE49243 [94], GSE12992 [95], GSE10327 [96], GSE37418 [97], GSE50161 [98], GSE44971 [99], GSE7307 [100], and GSE3526 [101]. UHPLC-MS/MS data is available at Figshare with DOI: https://doi.org/10.6084/m9.figshare.14397986.v1 [102]. All the key reagents are listed in Table S16. All the key reagents are listed in Table S16.

\section{Declarations}

\section{Ethics approval and consent to participate}

All animals were maintained and euthanized according to the Emory University Institutional Animal Care and Use Committee guidelines. The Institutional Review Board of Emory University and Xiangya Hospital approved the study. All the patients or their legal guardians enrolled in this study have given written informed consent for publication. All experimental methods comply with the Helsinki Declaration.

\section{Competing interests}

The authors declare no competing interests.

\section{Author details}

'Department of Human Genetics, Emory University School of Medicine, Atlanta, GA 30322, USA. ²Department of Biostatistics and Health Data Science, Indiana University School of Medicine, Indianapolis, IN 46202, USA. ${ }^{3}$ Laboratory of Molecular Neuro-Oncology, Department of Neurosurgery, Emory University School of Medicine, Atlanta, GA 30322, USA. ${ }^{4}$ Department of Hematology and Medical Oncology, Emory University School of Medicine, Atlanta, GA 30322, USA. ${ }^{5}$ Department of Pediatric Oncology, Emory University School of Medicine, Atlanta, GA 30322, USA. ${ }^{6}$ Winship Cancer Institute, Emory University, Atlanta, GA 30322, USA. ${ }^{7}$ Department of Neurosurgery, Xiangya Hospital, Central South University, Changsha 410008, Hunan, China. ${ }^{8}$ Hydrocephalus Center, Xiangya Hospital, Central South University, Changsha 410008, Hunan, China. ${ }^{9}$ The Children's Hospital and Institute of Translational Medicine, School of Medicine, Zhejiang University, Hangzhou, China. ${ }^{10}$ Department of Systems Biology and Gehr Family Center for Leukemia Research, City of Hope, Duarte, CA 91010, USA. ${ }^{11}$ Aflac Cancer and Blood Disorders Center, Children's Healthcare of Atlanta, Emory University School of Medicine, Atlanta, GA 30322, USA.

Received: 12 April 2020 Accepted: 15 April 2021

Published online: 29 April 2021

\section{References}

1. Pugh TJ, Weeraratne SD, Archer TC, Pomeranz Krummel DA, Auclair D, Bochicchio J, Carneiro MO, Carter SL, Cibulskis K, Erlich RL, Greulich H, Lawrence MS, Lennon NJ, McKenna A, Meldrim J, Ramos AH, Ross MG, Russ C, Shefler E, Sivachenko A, Sogoloff B, Stojanov P, Tamayo P, Mesirov JP, Amani V, Teider N, Sengupta S, Francois JP, Northcott PA, 
Taylor MD, et al. Medulloblastoma exome sequencing uncovers subtype-specific somatic mutations. Nature. 2012; 488(7409):106-10. https://doi.org/10.1038/nature11329.

2. Wang J, Garancher A, Ramaswamy V, Wechsler-Reya RJ. Medulloblastoma: from molecular subgroups to molecular targeted therapies. Annu Rev Neurosci. 2018;41(1):207-32. https://doi.org/10.1146/annurev-neuro-070815-013838.

3. Ellison DW, Dalton J, Kocak M, Nicholson SL, Fraga C, Neale G, Kenney AM, Brat DJ, Perry A, Yong WH, Taylor RE, Bailey S, Clifford SC, Gilbertson RJ. Medulloblastoma: clinicopathological correlates of SHH, WNT, and non-SHH/WNT molecular subgroups. Acta Neuropathol. 2011;121(3):381-96. https://doi.org/10.1007/s00401-011-0800-8.

4. Taylor MD, Northcott PA, Korshunov A, Remke M, Cho YJ, Clifford SC, Eberhart CG, Parsons DW, Rutkowski S, Gajjar A, Ellison DW, Lichter P, Gilbertson RJ, Pomeroy SL, Kool M, Pfister SM. Molecular subgroups of medulloblastoma: the current consensus. Acta Neuropathol. 2012;123(4):465-72. https://doi.org/10.1007/s00401-011-0922-z.

5. Cavalli FMG, Remke M, Rampasek L, Peacock J, Shih DJH, Luu B, Garzia L, Torchia J, Nor C, Morrissy AS, Agnihotri S, Thompson YY, Kuzan-Fischer CM, Farooq H, Isaev K, Daniels C, Cho BK, Kim SK, Wang KC, Lee JY, Grajkowska WA, PerekPolnik M, Vasiljevic A, Faure-Conter C, Jouvet A, Giannini C, Nageswara Rao AA, Li KKW, Ng HK, Eberhart CG, Pollack IF, Hamilton RL, Gillespie GY, Olson JM, Leary S, Weiss WA, Lach B, Chambless LB, Thompson RC, Cooper MK, Vibhakar R, Hauser P, van Veelen MLC, Kros JM, French PJ, Ra YS, Kumabe T, López-Aguilar E, Zitterbart K, Sterba J, Finocchiaro G, Massimino M, van Meir EG, Osuka S, Shofuda T, Klekner A, Zollo M, Leonard JR, Rubin JB, Jabado N, Albrecht S, Mora J, van Meter TE, Jung S, Moore AS, Hallahan AR, Chan JA, Tirapelli DPC, Carlotti CG, Fouladi M, Pimentel J, Faria CC, Saad AG, Massimi L, Liau LM, Wheeler H, Nakamura H, Elbabaa SK, Perezpeña-Diazconti M, Chico Ponce de León F, Robinson S, Zapotocky M, Lassaletta A, Huang A, Hawkins CE, Tabori U, Bouffet E, Bartels U, Dirks PB, Rutka JT, Bader GD, Reimand J, Goldenberg A, Ramaswamy V, Taylor MD. Intertumoral heterogeneity within medulloblastoma subgroups. Cancer Cell. 2017;31(6):737-754.e6. https://doi.org/10.1016/j.ccell.2017.05.005.

6. Ecke I, Petry F, Rosenberger A, Tauber S, Mönkemeyer S, Hess I, Dullin C, Kimmina S, Pirngruber J, Johnsen SA, Uhmann A, Nitzki F, Wojnowski L, Schulz-Schaeffer W, Witt O, Hahn H. Antitumor effects of a combined 5-aza-2'deoxycytidine and valproic acid treatment on rhabdomyosarcoma and medulloblastoma in Ptch mutant mice. Cancer Res. 2009;69(3): 887-95. https://doi.org/10.1158/0008-5472.CAN-08-0946.

7. Zhu D, Osuka S, Zhang Z, Reichert ZR, Yang L, Kanemura Y, Jiang Y, You S, Zhang H, Devi NS, Bhattacharya D, Takano S, Gillespie GY, Macdonald T, Tan C, Nishikawa R, Nelson WG, Olson JJ, Van Meir EG. BAl1 suppresses medulloblastoma formation by protecting p53 from Mdm2-mediated degradation. Cancer Cell. 2018;33(6):1004-1016.e5. https://doi.org/1 0.1016/j.ccell.2018.05.006.

8. Sidman RL, Rakic P. Neuronal migration, with special reference to developing human brain: a review. Brain Res. 1973; 62(1):1-35. https://doi.org/10.1016/0006-8993(73)90617-3.

9. Ten Donkelaar HJ, Lammens M, Wesseling P, Hori A. Development and developmental disorders of the human cerebellum. In: Clinical Neuroembryology: Development and Developmental Disorders of the Human Central Nervous System; 2014.

10. Song CX, Szulwach KE, Fu Y, Dai Q, Yi C, Li X, Li Y, Chen CH, Zhang W, Jian X, Wang J, Zhang L, Looney TJ, Zhang B, Godley LA, Hicks LM, Lahn BT, Jin P, He C. Selective chemical labeling reveals the genome-wide distribution of 5hydroxymethylcytosine. Nat Biotechnol. 2011;29(1):68-72. https://doi.org/10.1038/nbt.1732.

11. Zhu X, Girardo D, Govek EE, John K, Mellén M, Tamayo P, Mesirov JP, Hatten ME. Role of Tet1/3 genes and chromatin remodeling genes in cerebellar circuit formation. Neuron. 2016;89(1):100-12. https://doi.org/10.1016/j.neuron.2015.11.030.

12. Wang T, Pan Q, Lin L, Szulwach KE, Song CX, He C, Wu H, Warren ST, Jin P, Duan R, Li X. Genome-wide DNA hydroxymethylation changes are associated with neurodevelopmental genes in the developing human cerebellum. Hum Mol Genet. 2012;21(26):5500-10. https://doi.org/10.1093/hmg/dds394.

13. Lian CG, Xu Y, Ceol C, Wu F, Larson A, Dresser K, Xu W, Tan L, Hu Y, Zhan Q, Lee C-W, Hu D, Lian BQ, Kleffel S, Yang Y, Neiswender J, Khorasani AJ, Fang R, Lezcano C, Duncan LM, Scolyer RA, Thompson JF, Kakavand H, Houvras Y, Zon LI, Mihm MC, Kaiser UB, Schatton T, Woda BA, Murphy GF, et al. Loss of 5-hydroxymethylcytosine is an epigenetic hallmark of melanoma. Cell. 2012;150(6):1135-46. https://doi.org/10.1016/j.cell.2012.07.033.

14. Uribe-Lewis S, Stark R, Carroll T, Dunning MJ, Bachman M, Ito Y, Stojic L, Halim S, Vowler SL, Lynch AG, Delatte B, de Bony EJ, Colin L, Defrance M, Krueger F, Silva A-L, ten Hoopen R, Ibrahim AE, Fuks F, Murrell A. 5-hydroxymethylcytosine marks promoters in colon that resist DNA hypermethylation in cancer. Genome Biol. 2015;16:30-5.

15. Yang H, Liu Y, Bai F, Zhang J-Y, Ma S-H, Liu J, Xu Z-D, Zhu H-G, Ling Z-Q, Ye D, Guan K-L, Xiong Y. Tumor development is associated with decrease of TET gene expression and 5-methylcytosine hydroxylation. Oncogene. 2013;32(5):663-9.

16. Jin SG, Wu X, Li AX, Pfeifer GP. Genomic mapping of 5-hydroxymethylcytosine in the human brain. Nucleic Acids Res. 2011;39(12):5015-24. https://doi.org/10.1093/nar/gkr120.

17. Kraus TFJ, Globisch D, Wagner M, Eigenbrod S, Widmann D, Münzel M, Müller M, Pfaffeneder T, Hackner B, Feiden W, Schüller U, Carell T, Kretzschmar HA. Low values of 5-hydroxymethylcytosine $(5 \mathrm{hmC})$, the "sixth base," are associated with anaplasia in human brain tumors. Int J Cancer. 2012;131(7):1577-90. https://doi.org/10.1002/ijc.27429.

18. Orr BA, Haffner MC, Nelson WG, Yegnasubramanian S, Eberhart CG. Decreased 5-hydroxymethylcytosine is associated with neural progenitor phenotype in normal brain and shorter survival in malignant glioma. Plos One. 2012;7(7):e41036. https://doi.org/10.1371/journal.pone.0041036.

19. Kudo Y, Tateishi K, Yamamoto K, Yamamoto S, Asaoka Y, ljichi H, Nagae G, Yoshida H, Aburatani H, Koike K. Loss of 5hydroxymethylcytosine is accompanied with malignant cellular transformation. Cancer Sci. 2012;103(4):670-6. https:// doi.org/10.1111/j.1349-7006.2012.02213.x.

20. Müller T, Gessi M, Waha A, Isselstein LJ, Luxen D, Freihoff D, Freihoff J, Becker A, Simon M, Hammes J, Denkhaus D, zur Mühlen A, Pietsch T, Waha A. Nuclear exclusion of TET1 is associated with loss of 5-hydroxymethylcytosine in IDH1 wildtype gliomas. Am J Pathol. 2012;181(2):675-83. https://doi.org/10.1016/j.ajpath.2012.04.017.

21. Good CR, Madzo J, Patel B, Maegawa S, Engel N, Jelinek J, Issa JPJ. A novel isoform of TET1 that lacks a CXXC domain is overexpressed in cancer. Nucleic Acids Res. 2017;45(14):8269-81. https://doi.org/10.1093/nar/gkx435.

22. Chou WC, Chou SC, Liu CY, Chen CY, Hou HA, Kuo YY, Lee MC, Ko BS, Tang JL, Yao M, Tsay W, Wu SJ, Huang SY, Hsu SC, Chen YC, Chang YC, Kuo YY, Kuo KT, Lee FY, Liu MC, Liu CW, Tseng MH, Huang CF, Tien HF. TET2 mutation is an unfavorable prognostic factor in acute myeloid leukemia patients with intermediate-risk cytogenetics. Blood. 2011; 118(14):3803-10. 
23. Ficz G, Gribben JG. Loss of 5-hydroxymethylcytosine in cancer: cause or consequence? Genomics. 2014;104(5):352-7. https://doi.org/10.1016/j.ygeno.2014.08.017.

24. Jin SG, Jiang Y, Qiu R, Rauch TA, Wang Y, Schackert G, Krex D, Lu Q, Pfeifer GP. 5-hydroxymethylcytosine is strongly depleted in human cancers but its levels do not correlate with IDH1 mutations. Cancer Res. 2011;71(24):7360-5. https:// doi.org/10.1158/0008-5472.CAN-11-2023

25. Ko M, Huang Y, Jankowska AM, Pape UJ, Tahiliani M, Bandukwala HS, An J, Lamperti ED, Koh KP, Ganetzky R, Liu XS, Aravind L, Agarwal S, Maciejewski JP, Rao A. Impaired hydroxylation of 5-methylcytosine in myeloid cancers with mutant TET2. Nature. 2010;468(7325):839-43. https://doi.org/10.1038/nature09586.

26. Ruzov A, Tsenkina Y, Serio A, Dudnakova T, Fletcher J, Bai Y, Chebotareva T, Pells S, Hannoun Z, Sullivan G, Chandran S, Hay DC, Bradley M, Wilmut I, De Sousa P. Lineage-specific distribution of high levels of genomic 5hydroxymethylcytosine in mammalian development. Cell Res. 2011;21(9):1332-42. https://doi.org/10.1038/cr.2011.113.

27. Pfeifer GP, Xiong W, Hahn MA, Jin SG. The role of 5-hydroxymethylcytosine in human cancer. Cell Tissue Res. 2014, 356(3):631-41. https://doi.org/10.1007/s00441-014-1896-7.

28. Xu W, Yang H, Liu Y, Yang Y, Wang P, Kim SH, Ito S, Yang C, Wang P, Xiao MT, Liu LX, Jiang WQ, Liu J, Zhang JY, Wang B, Frye S, Zhang Y, Xu YH, Lei QY, Guan KL, Zhao SM, Xiong Y. Oncometabolite 2-hydroxyglutarate is a competitive inhibitor of a-ketoglutarate-dependent dioxygenases. Cancer Cell. 2011;19(1):17-30. https://doi.org/10.1016/j.ccr.2010.12.014.

29. Massé A, Vainchenker W, Dupont S, Alberdi A, Delhommeau F, Fontenay M, Robert F, Lécluse Y, Plo I, Viguié F, Dreyfus FJ, Dessen P, Bernard OA, James C, Marzac C, Le Couedic J-P, Soulier J, Romana SP, Valle V Della, Trannoy S, Lacombe C, Casadevall N, Kosmider O. Mutation in TET2 in Myeloid Cancers. N Engl J Med. 2009;360:2289-301.

30. Gao J, Aksoy BA, Dogrusoz U, Dresdner G, Gross B, Sumer SO, Sun Y, Jacobsen A, Sinha R, Larsson E, Cerami E, Sander C, Schultz N. Integrative analysis of complex cancer genomics and clinical profiles using the cBioPortal. Sci Signal. 2013; 6(269):pl1. https://doi.org/10.1126/scisignal.2004088.

31. Cerami E, Gao J, Dogrusoz U, Gross BE, Sumer SO, Aksoy BA, Jacobsen A, Byrne CJ, Heuer ML, Larsson E, Antipin Y, Reva B, Goldberg AP, Sander C, Schultz N. The cBio Cancer Genomics Portal: an open platform for exploring multidimensional cancer genomics data. Cancer Discov. 2012;2(5):401-4. https://doi.org/10.1158/2159-8290.CD-12-0095

32. Northcott PA, Buchhalter I, Morrissy AS, Hovestadt V, Weischenfeldt J, Ehrenberger T, Gröbner S, Segura-Wang M, Zichner T, Rudneva VA, Warnatz HJ, Sidiropoulos N, Phillips AH, Schumacher S, Kleinheinz K, Waszak SM, Erkek S, Jones DTW, Worst BC, Kool M, Zapatka M, Jäger N, Chavez L, Hutter B, Bieg M, Paramasivam N, Heinold M, Gu Z, Ishaque N, Jäger-Schmidt C, Imbusch CD, Jugold A, Hübschmann D, Risch T, Amstislavskiy V, Gonzalez FGR, Weber UD, Wolf S, Robinson GW, Zhou X, Wu G, Finkelstein D, Liu Y, Cavalli FMG, Luu B, Ramaswamy V, Wu X, Koster J, Ryzhova M, Cho YJ, Pomeroy SL, Herold-Mende C, Schuhmann M, Ebinger M, Liau LM, Mora J, McLendon RE, Jabado N, Kumabe T, Chuah E, Ma Y, Moore RA, Mungall AJ, Mungall KL, Thiessen N, Tse K, Wong T, Jones SJM, Witt O, Milde T, von Deimling A, Capper D, Korshunov A, Yaspo ML, Kriwacki R, Gajjar A, Zhang J, Beroukhim R, Fraenkel E, Korbel JO, Brors B, Schlesner M, Eils R, Marra MA, Pfister SM, Taylor MD, Lichter P. The whole-genome landscape of medulloblastoma subtypes. Nature. 2017;547(7663):311-7. https://doi.org/10.1038/nature22973.

33. Vincent JJ, Huang Y, Chen PY, Feng S, Calvopiña JH, Nee K, Lee SA, Le T, Yoon AJ, Faull K, Fan G, Rao A, Jacobsen SE, Pellegrini M, Clark AT. Stage-specific roles for Tet1 and Tet2 in DNA demethylation in primordial germ cells. Cell Stem Cell. 2013;12(4):470-8. https://doi.org/10.1016/.j.stem.2013.01.016.

34. Hackett JA, Sengupta R, Zylicz JJ, Murakami K, Lee C, Down TA, Surani MA. Germline DNA demethylation dynamics and imprint erasure through 5-hydroxymethylcytosine. Science. 2013;339(6118):448-52.

35. Hashimoto S, Kojima N, Okamoto Y, Seki Y, Sugasawa K, Okashita N, Takada T, Ebi K, Kumaki Y, Nakamura T, Nishi M, Nakayama M, Okano M. PRDM14 promotes active DNA demethylation through the Ten-eleven translocation (TET)mediated base excision repair pathway in embryonic stem cells. Development. 2013;141(2):269-80.

36. Hovestadt V, Jones DTW, Picelli S, Wang W, Kool M, Northcott PA, Sultan M, Stachurski K, Ryzhova M, Warnatz H-J, Ralser M, Brun S, Bunt J, Jäger N, Kleinheinz K, Erkek S, Weber UD, Bartholomae CC, von Kalle C, Lawerenz C, Eils J, Koster J, Versteeg R, Milde T, Witt O, Schmidt S, Wolf S, Pietsch T, Rutkowski S, Scheurlen W, et al. Decoding the regulatory landscape of medulloblastoma using DNA methylation sequencing. Nature. 2014;510(7506):537-41. https://doi.org/10.1 038/nature13268

37. Nestor CE, Ottaviano R, Reddington J, Sproul D, Reinhardt D, Dunican D, Katz E, Dixon JM, Harrison DJ, Meehan RR. Tissue type is a major modifier of the 5-hydroxymethylcytosine content of human genes. Genome Res. 2012;22(3):46777. https://doi.org/10.1101/gr.126417.111.

38. Li W, Liu M. Distribution of 5-Hydroxymethylcytosine in different human tissues. J Nucleic Acids. 2011;2011:1-5. https:// doi.org/10.4061/2011/870726.

39. Johnson KC, Houseman EA, King JE, Von Herrmann KM, Fadul CE, Christensen BC. 5-Hydroxymethylcytosine localizes to enhancer elements and is associated with survival in glioblastoma patients. Nat Commun. 2016;7(1) https://doi.org/10. 038/ncomms13177.

40. Love MI, Huber W, Anders S. Moderated estimation of fold change and dispersion for RNA-seq data with DESeq2. Genome Biol. 2014;15(12):550. https://doi.org/10.1186/s13059-014-0550-8.

41. Supek F, Lehner B, Hajkova P, Warnecke T. Hydroxymethylated cytosines are associated with elevated C to G transversion rates. Plos Genet. 2014;10(9):e1004585. https://doi.org/10.1371/journal.pgen.1004585.

42. Wu H, D'Alessio AC, Ito S, Wang Z, Cui K, Zhao K, Sun YE, Zhang Y. Genome-wide analysis of 5-hydroxymethylcytosine distribution reveals its dual function in transcriptional regulation in mouse embryonic stem cells. Genes Dev. 2011;25(7): 679-84. https://doi.org/10.1101/gad.2036011

43. Hahn MA, Qiu R, Wu X, Li AX, Zhang H, Wang J, Jui J, Jin S-G, Jiang Y, Pfeifer GP, Lu Q. Dynamics of 5hydroxymethylcytosine and chromatin marks in mammalian neurogenesis. Cell Rep. 2013;3(2):291-300. https://doi.org/1 0.1016/j.celrep.2013.01.011.

44. Yao B, Lin L, Street RC, Zalewski ZA, Galloway JN, Wu H, Nelson DL, Jin P. Genome-wide alteration of 5hydroxymethylcytosine in a mouse model of fragile X-associated tremor/ataxia syndrome. Hum Mol Genet. 2014;23(4): 1095-107. https://doi.org/10.1093/hmg/ddt504.

45. Sardina JL, Collombet S, Tian TV, Gómez A, Di Stefano B, Berenguer C, Brumbaugh J, Stadhouders R, Segura-Morales C, Gut M, Gut IG, Heath S, Aranda S, Di Croce L, Hochedlinger K, Thieffry D, Graf T. Transcription factors drive Tet2- 
mediated enhancer demethylation to reprogram cell fate. Cell Stem Cell. 2018;23(6):905-6. https://doi.org/10.1016/j. stem.2018.11.001

46. Lin CY, Erkek S, Tong Y, Yin L, Federation AJ, Zapatka M, Haldipur P, Kawauchi D, Risch T, Warnatz HJ, Worst BC, Ju B, Orr BA, Zeid R, Polaski DR, Segura-Wang M, Waszak SM, Jones DTW, Kool M, Hovestadt V, Buchhalter I, Sieber L, Johann P, Chavez L, Gröschel S, Ryzhova M, Korshunov A, Chen W, Chizhikov W, Millen KJ, Amstislavskiy V, Lehrach H, Yaspo ML, Eils R, Lichter P, Korbel JO, Pfister SM, Bradner JE, Northcott PA. Active medulloblastoma enhancers reveal subgroupspecific cellular origins. Nature. 2016;530(7588):57-62. https://doi.org/10.1038/nature16546.

47. Heinz S, Benner C, Spann N, Bertolino E, Lin YC, Laslo P, Cheng JX, Murre C, Singh H, Glass CK: Simple Combinations of Lineage-Determining Transcription Factors Prime cis-Regulatory Elements Required for Macrophage and B Cell Identities. Mol Cell. 2010;38(4):576-89.

48. Costa Y, Ding J, Theunissen TW, Faiola F, Hore TA, Shliaha PV, Fidalgo M, Saunders A, Lawrence M, Dietmann S, Das S, Levasseur DN, Li Z, Xu M, Reik W, Silva JC, Wang J. NANOG-dependent function of TET1 and TET2 in establishment of pluripotency. Nature. 2013;495(7441):370-4. https://doi.org/10.1038/nature11925.

49. Zhu G, Li Y, Zhu F, Wang T, Jin W, Mu W, Lin W, Tan W, Li W, Street RC, Peng S, Zhang J, Feng Y, Warren ST, Sun $Q$, Jin P, Chen D. Coordination of engineered factors with TET1/2 promotes early-stage epigenetic modification during somatic cell reprogramming. Stem Cell Rep. 2014;2(3):253-61. https://doi.org/10.1016/j. stemcr.2014.01.012.

50. Hoshino M, Nakamura S, Mori K, Kawauchi T, Terao M, Nishimura W, Fukuda A, Fuse T, Matsuo N, Sone M, Watanabe M, Bito H, Terashima T, Wright CVE, Kawaguchi Y, Nakao K, Nabeshima YI. Ptf1a, a bHLH transcriptional gene, defines GABAergic neuronal fates in cerebellum. Neuron. 2005;47(2):201-13. https://doi.org/10.1016/j.neuron.2005.06.007.

51. Li Y, Brauer PM, Singh J, Xhiku S, Yoganathan K, Zúñiga-Pflücker JC, Anderson MK. Targeted disruption of TCF12 reveals HEB as essential in human mesodermal specification and hematopoiesis. Stem Cell Rep. 2017;9(3):779-95. https://doi. org/10.1016/j.stemcr.2017.07.011.

52. Schüller U, Heine VM, Mao J, Kho AT, Dillon AK, Han YG, Huillard E, Sun T, Ligon AH, Qian Y, Ma Q, Alvarez-Buylla A, McMahon AP, Rowitch DH, Ligon KL: Acquisition of granule neuron precursor identity is a critical determinant of progenitor cell competence to form Shh-induced medulloblastoma. Cancer Cell 2008.

53. Schüller U, Heine VM, Mao J, Kho AT, Dillon AK, Han YG, Huillard E, Sun T, Ligon AH, Qian Y, Ma Q, Alvarez-Buylla A, McMahon AP, Rowitch DH, Ligon KL. Acquisition of Granule Neuron Precursor Identity Is a Critical Determinant of Progenitor Cell Competence to Form Shh-Induced Medulloblastoma. Cancer Cell. 2008;14(2):123-34.

54. Hallahan AR, Pritchard JI, Hansen S, Benson M, Stoeck J, Hatton BA, Russell TL, Ellenbogen RG, Bernstein ID, Beachy PA, Olson JM. The SmoA1 mouse model reveals that notch signaling is critical for the growth and survival of sonic hedgehog-induced medulloblastomas. Cancer Res. 2004;64(21):7794-800. https://doi.org/10.1158/ 0008-5472.CAN-04-1813.

55. Hatton BA, Villavicencio EH, Tsuchiya KD, Pritchard Jl, Ditzler S, Pullar B, Hansen S, Knoblaugh SE, Lee D, Eberhart CG, Hallahan AR, Olson JM. The Smo/Smo model: Hedgehog-induced medulloblastoma with 90\% incidence and leptomeningeal spread. Cancer Res. 2008;68(6):1768-76. https://doi.org/10.1158/0008-5472.CAN-07-5092.

56. Jiang $X$, Hu C, Ferchen $K$, Nie J, Cui X, Chen CH, Cheng L, Zuo Z, Seibel W, He C, Tang Y, Skibbe JR, Wunderlich M, Reinhold WC, Dong L, Shen C, Arnovitz S, Ulrich B, Lu J, Weng H, Su R, Huang H, Wang Y, Li C, Qin X, Mulloy J, Zheng Y, Diao J, Jin J, Li C, et al. Targeted inhibition of STAT/TET1 axis as a therapeutic strategy for acute myeloid leukemia. Nat Commun. 2017;8(1):2099. https://doi.org/10.1038/s41467-017-02290-w.

57. Chen X, Xu H, Yuan P, Fang F, Huss M, Vega VB, Wong E, Orlov YL, Zhang W, Jiang J, et al. Integration of external signaling pathways with the core transcriptional network in embryonic stem cells. Cell. 2008;133:1106-17.

58. Marson A, Levine SS, Cole MF, Frampton GM, Brambrink T, Johnstone S, Guenther MG, Johnston WK, Wernig M, Newman J, et al. Connecting microRNA genes to the core transcriptional regulatory circuitry of embryonic stem cells. Cell. 2008;134:521-33.

59. Williams K, Christensen J, Pedersen MT, Johansen JV, Cloos PA, Rappsilber J, Helin K. TET1 and hydroxymethylcytosine in transcription and DNA methylation fidelity. Nature. 2011;473(7347):343-8. https://doi.org/10.1038/nature10066.

60. Tate JG, Bamford S, Jubb HC, Sondka Z, Beare DM, Bindal N, Boutselakis H, Cole CG, Creatore C, Dawson E, Fish P, Harsha B, Hathaway C, Jupe SC, Kok CY, Noble K, Ponting L, Ramshaw CC, Rye CE, Speedy HE, Stefancsik R, Thompson SL, Wang S, Ward S, Campbell PJ, Forbes SA. COSMIC: the catalogue of somatic mutations in cancer. Nucleic Acids Res. 2019;47(D1):D941-7. https://doi.org/10.1093/nar/gky1015.

61. MacDonald TJ, Brown KM, Lafleur B, Peterson K, Lawlor C, Chen Y, Packer RJ, Cogen P, Stephan DA. Expression profiling of medulloblastoma: PDGFRA and the RAS/MAPK pathway as therapeutic targets for metastatic disease. Nat Genet. 2001;29(2):143-52. https://doi.org/10.1038/ng731.

62. Gilbertson RJ, Clifford SC. PDGFRB is overexpressed in metastatic medulloblastoma. Nat Genet. 2003;35(3):197-8. https:// doi.org/10.1038/ng1103-197.

63. Northcott PA, Korshunov A, Witt H, Hielscher T, Eberhart CG, Mack S, Bouffet E, Clifford SC, Hawkins CE, French P, Rutka JT, Pfister S, Taylor MD. Medulloblastoma comprises four distinct molecular variants. J Clin Oncol. 2011;29(11):1408-14. https://doi.org/10.1200/JCO.2009.27.4324.

64. Zhukova N, Ramaswamy V, Remke M, Pfaff E, Shih DJH, Martin DC, Castelo-Branco P, Baskin B, Ray PN, Bouffet E, Von Bueren AO, Jones DTW, Northcott PA, Kool M, Sturm D, Pugh TJ, Pomeroy SL, Cho YJ, Pietsch T, Gessi M, Rutkowski S, Bognar L, Klekner A, Cho BK, Kim SK, Wang KC, Eberhart CG, Fevre-Montange M, Fouladi M, French PJ, et al. Subgroupspecific prognostic implications of TP53 mutation in medulloblastoma. J Clin Oncol. 2013;31(23):2927-35. https://doi. org/10.1200/JCO.2012.48.5052

65. Schwalbe EC, Lindsey JC, Nakjang S, Crosier S, Smith AJ, Hicks D, Rafiee G, Hill RM, lliasova A, Stone T, Pizer B, Michalski A, Joshi A, Wharton SB, Jacques TS, Bailey S, Williamson D, Clifford SC. Novel molecular subgroups for clinical classification and outcome prediction in childhood medulloblastoma: a cohort study. Lancet Oncol. 2017;18(7):958-71. https://doi.org/10.1016/S1470-2045(17)30243-7.

66. Stroud H, Feng S, Morey Kinney S, Pradhan S, Jacobsen SE. 5-Hydroxymethylcytosine is associated with enhancers and gene bodies in human embryonic stem cells. Genome Biol. 2011;12(6):R54. https://doi.org/10.1186/gb-2011-12-6-r54. 
67. Po A, Ferretti E, Miele E, De Smaele E, Paganelli A, Canettieri G, Coni S, Di Marcotullio L, Biffoni M, Massimi L, Di Rocco C, Screpanti I, Gulino A. Hedgehog controls neural stem cells through p53-independent regulation of Nanog. EMBO J. 2010;29(15):2646-58. https://doi.org/10.1038/emboj.2010.131.

68. Barnes KC, Sigaux F, Margolin A, Young RA, O'Neil J, Aster JC, Soulier J, Weng AP, Look AT, Odom DT, Lim WK, Ferrando AA, Sulis ML, Real PJ, Neuberg D, Palomero T, Califano A. NOTCH1 directly regulates C-MYC and activates a feedforward-loop transcriptional network promoting leukemic cell growth. Proc Natl Acad Sci. 2006;103(48):18261-6.

69. Ee P-LR, Bhat U, Cho S, He X, Schneider E, Lu M, Miele L, Beck WT. Notch1 regulates the expression of the multidrug resistance gene ABCC1/MRP1 in cultured cancer cells. Proc Natl Acad Sci. 2011;108(51):20778-83.

70. Tahiliani M, Koh KP, Shen Y, Pastor WA, Bandukwala H, Brudno Y, Agarwal S, lyer LM, Liu DR, Aravind L, Rao A. Conversion of 5-methylcytosine to 5-hydroxymethylcytosine in mammalian DNA by MLL partner TET1. Science. 2009; 324(5929):930-5. https://doi.org/10.1126/science.1170116.

71. Kriaucionis $\mathrm{S}$, Heintz N. The nuclear DNA base 5-hydroxymethylcytosine is present in Purkinje neurons and the brain. Science. 2009;324:929-30.

72. Bonvin E, Radaelli E, Bizet M, Luciani F, Calonne E, Putmans P, Nittner D, Singh NK, Santagostino SF, Petit V, Larue L, Marine JC, Fuks F. TET2-dependent hydroxymethylome plasticity reduces melanoma initiation and progression. Cancer Res. 2019;79(3):482-94. https://doi.org/10.1158/0008-5472.CAN-18-1214.

73. Takai H, Masuda K, Sato T, Sakaguchi Y, Suzuki T, Suzuki T, Koyama-Nasu R, Nasu-Nishimura Y, Katou Y, Ogawa H, Morishita Y, Kozuka-Hata H, Oyama M, Todo T, Ino Y, Mukasa A, Saito N, Toyoshima C, Shirahige K, Akiyama T. 5Hydroxymethylcytosine plays a critical role in glioblastomagenesis by recruiting the CHTOP-methylosome complex. Cell Rep. 2014;9(1):48-60. https://doi.org/10.1016/j.celrep.2014.08.071.

74. López-Moyado IF, Tsagaratou A, Yuita H, Seo H, Delatte B, Heinz S, Benner C, Rao A. Paradoxical association of TET loss of function with genome-wide DNA hypomethylation. Proc Natl Acad Sci. 2019;116(34):16933-42. https://doi.org/10.1 073/pnas. 1903059116.

75. Huang Y, Chavez L, Chang X, Wang X, Pastor WA, Kang J, Zepeda-Martínez JA, Pape UJ, Jacobsen SE, Peters B, Rao A. Distinct roles of the methylcytosine oxidases Tet1 and Tet2 in mouse embryonic stem cells. Proc Natl Acad Sci U S A. 2014;111(4):1361-6. https://doi.org/10.1073/pnas.1322921111.

76. Dawlaty MM, Ganz K, Powell BE, Hu YC, Markoulaki S, Cheng AW, Gao Q, Kim J, Choi SW, Page DC, Jaenisch R. Tet1 is dispensable for maintaining pluripotency and its loss is compatible with embryonic and postnatal development. Cell Stem Cell. 2011;9(2):166-75. https://doi.org/10.1016/j.stem.2011.07.010.

77. Ko M, Bandukwala HS, An J, Lamperti ED, Thompson EC, Hastie R, Tsangaratou A, Rajewsky K, Koralov SB, Rao A. Teneleven-translocation 2 (TET2) negatively regulates homeostasis and differentiation of hematopoietic stem cells in mice. Proc Natl Acad Sci U S A. 2011;108(35):14566-71. https://doi.org/10.1073/pnas.1112317108.

78. Wilson CL, Miller CJ. Simpleaffy: a BioConductor package for Affymetrix quality control and data analysis. Bioinformatics. 2005;21(18):3683-5. https://doi.org/10.1093/bioinformatics/bti605.

79. Ritchie ME, Phipson B, Wu D, Hu Y, Law CW, Shi W, Smyth GK. Limma powers differential expression analyses for RNAsequencing and microarray studies. Nucleic Acids Res. 2015;43(7):e47.

80. Wickham H. ggplot2: Elegant Graphics for Data Analysis. New York: Springer-Verlag; 2009.

81. Song CX, Clark TA, Lu XY, Kislyuk A, Dai Q, Turner SW, He C, Korlach J. Sensitive and specific single-molecule sequencing of 5-hydroxymethylcytosine. Nat Methods. 2011;9(1):75-7. https://doi.org/10.1038/nmeth.1779.

82. Langmead B, Salzberg SL. Fast gapped-read alignment with Bowtie 2. Nat Methods. 2012;9(4):357-9. https://doi.org/10.1 038/nmeth.1923.

83. Li H, Handsaker B, Wysoker A, Fennell T, Ruan J, Homer N, Marth G, Abecasis G, Durbin R. The sequence alignment/map format and SAMtools. Bioinformatics. 2009;25(16):2078-9. https://doi.org/10.1093/bioinformatics/btp352.

84. Broad Institute: Picard:A set of command line tools (in Java) for manipulating high-throughput sequencing (HTS) data and formats such as SAM/BAM/CRAM and VCF. http://broadinstitute.github.io/picard/ 2016.

85. Shin H, Liu T, Manrai AK, Liu SX. CEAS: Cis-regulatory element annotation system. Bioinformatics. 2009;25(19):2605-6. https://doi.org/10.1093/bioinformatics/btp479.

86. McLean CY, Bristor D, Hiller M, Clarke SL, Schaar BT, Lowe CB, Wenger AM, Bejerano G. GREAT improves functional interpretation of cis-regulatory regions. Nat Biotechnol. 2010;28(5):495-501. https://doi.org/10.1038/nbt.1630.

87. Fischer AH, Jacobson KA, Rose J, Zeller R. Hematoxylin and eosin staining of tissueand cell sections. Cold Spring Harb Protoc. 2008;2008(6) https://doi.org/10.1101/pdb.prot4986.

88. Pertea M, Kim D, Pertea GM, Leek JT, Salzberg SL. Transcript-level expression analysis of RNA-seq experiments with HISA T, StringTie and Ballgown. Nat Protoc. 2016;11(9):1650-67.

89. Mi H, Muruganujan A, Ebert D, Huang X, Thomas PD. PANTHER version 14: more genomes, a new PANTHER GO-slim and improvements in enrichment analysis tools. Nucleic Acids Res. 2019;47(D1):D419-26. https://doi.org/10.1093/nar/ gky1038.

90. Nikolsky Y, Bryant J. Protein networks and pathway analysis. Preface. Methods in molecular biology. 2009;563:v-vii.

91. Quinlan AR, Hall IM. BEDTools: a flexible suite of utilities for comparing genomic features. Bioinformatics. 2010;26(6):8412. https://doi.org/10.1093/bioinformatics/btq033.

92. Kim, Hyerim and Jin, Peng. Genome-wide 5-hydroxymethylcytosine alterations in medulloblastoma. Gene Expression Omnibus. https://www.ncbi.nlm.nih.gov/geo/query/acc.cgi?acc=GSE74336 (2021). Accessed 6 Apr 2021.

93. Kim, Hyerim and Jin, Peng. Medulloblastoma from human patients and mouse model Raw sequence reads. SRA .2019. https://www.ncbi.nlm.nih.gov/bioproject/PRJNA554937/. Accessed 1 Jan 2020.

94. Kool M and Pfister S. Gene expression data from medulloblastoma tumor samples. Gene Expression Omnibus. 2014. https://www.ncbi.nlm.nih.gov/geo/query/acc.cgi?acc=GSE49243. Accessed 2 Jun 2014.

95. Fattet $S$, Haberler C, Legoix P, Varlet P, Lellouch-Tubiana A, Lair S, Manie E, Raquin M, Bours D, Carpentier S, Barillot E, Grill J, Doz F, Puget S, Janoueix-Lerosey I, Delattre O, Beta-catenin status in pediatric medulloblastomas. GSE12992. Gene Expression Omnibus. 2009. https://www.ncbi.nlm.nih.gov/geo/query/acc.cgi?acc=GSE12992. Accessed 2 Feb 2009.

96. Kool M, Pietsch T, Clifford S, Versteeg R. mRNA expression data of 62 human medulloblastoma tumors. Gene Expression Omnibus. 2008. https://www.ncbi.nlm.nih.gov/geo/query/acc.cgi?acc=GSE10327. Accessed 2 Sept 2008. 
97. Robinson G, Parker M, Kranenburg TA, Lu C, Chen X, Ding L, Phoenix TN, Hedlund E, Wei L, Zhu X, Chalhoub N, Baker SJ, Huether R, Kriwacki R, Curley N, Thiruvenkatam R, Wang J, Wu G, Rusch M, Hong X, Beckford J, Gupta P, Ma J, Easton J, Vadodaria B, Onar-Thomas A, Lin T, Li S, Pounds S, Paugh S, Zhao D, Kawauchi D, Roussel MF, Finkelstein D, Ellison DW, Lau CC, Bouffet E, Hassall T, Gururangan S, Cohn R, Fulton1 RS, Fulton LL, Dooling DJ, Ochoa K, Gajjar A, Mardis ER, Wilson RK, Downing JR, Zhang J, Gilbertson RJ. Novel mutations target distinct subgroups of medulloblastoma. Gene Expression Omnibus. 2012. https://www.ncbi.nlm.nih.gov/geo/query/acc.cgi?acc=GSE37418. Accessed 6 Jul 2012.

98. Donson AM. Expression data from human brain tumors and human normal brain. Gene Expression Omnibus. 2013. https://www.ncbi.nIm.nih.gov/geo/query/acc.cgi?acc=GSE50161. Accessed 25 Aug 2013.

99. Lambert SR, Witt H, Hovestadt V, Zucknick M, Kool M, Pearson DM, Korshunov A, Ryzhova M, Ichimura K, Jabado N, Fontebasso A, Lichter P, Pfister SM, Collins VP, Jones DT. Gene expression data from pilocytic astrocytoma tumour samples and normal cerebellum controls. Gene Expression Omnibus. 2013. https://www.ncbi.nlm.nih.gov/geo/query/acc cgi?acc=GSE44971. 12 Jun 2013

100. Roth R. Human body index - transcriptional profiling. Gene Expression Omnibus. 2007. https://www.ncbi.nlm.nih.gov/ geo/query/acc.cgi?acc=GSE7307. Accessed 9 Apr 2007.

101. Roth RB. Comparison of gene expression profiles across the normal human body. Gene Expression Omnibus. 2006 https://www.ncbi.nlm.nih.gov/geo/query/acc.cgi?acc=GSE3526. Accessed 30 Mar 2006.

102. Jin P. Summary of 5hmdC amd dC in human normal cerebulla $(n=5)$ and huamn MBs ( $n=24)$. figshare. Dataset. 2021. doi: https://doi.org/10.6084/m9.figshare.14397986.v1

\section{Publisher's Note}

Springer Nature remains neutral with regard to jurisdictional claims in published maps and institutional affiliations.

\section{Ready to submit your research? Choose BMC and benefit from:}

- fast, convenient online submission

- thorough peer review by experienced researchers in your field

- rapid publication on acceptance

- support for research data, including large and complex data types

- gold Open Access which fosters wider collaboration and increased citations

- maximum visibility for your research: over $100 \mathrm{M}$ website views per year

At $\mathrm{BMC}$, research is always in progress.

Learn more biomedcentral.com/submissions 